\title{
A System Dynamics Model of Socio-technical Regime Transitions
}

\begin{abstract}
Formal modelling of sociotechnical studies has so far focused either on reproducing known historical case studies or on generic transition models that encompass some of the characteristics of the underlying processes. This article presents a model that captures the unfolding dynamics of an existing technological regime and the emerging niches as they compete and respond to landscape pressures. The theoretical basis is the "Multi-Level Perspective" (MLP) framework. The development of new technologies in niches is endogenous and stochastic. Model analysis can be seen as a test of the dynamic consistency of the MLP substitution pathway. Simulation results are consistent with what MLP theory suggests and raise relevant questions and insights with regard to future modelling work on transition pathways and theory development.
\end{abstract}

Keywords: formal modelling, system dynamics, transition mechanisms, transition pathways.

\section{Introduction}

Research on sociotechnical transitions and system innovations can offer insight about the factors that enable or inhibit widespread adoption of environmentally sustainable or energy efficient technologies. One influential framework developed in this context is the Multi Level Perspective (MLP) (Geels and Schot, 2007; Geels, 2004; Rip and Kemp, 1998). It has formed the basis for various case studies on sociotechnical transitions (Geels, 2002; 2005; 2006a; 2006b; 2007a; 2007b; Raven 2004; Verbong and Geels, 2007; Van den Vleuten and Raven, 2006; Raven, 2007). However, relatively few modelling studies following the MLP have shed light on transitions so far (e.g., Yucel and Mesa 2008; Kohler et al., 2009; Yucel and van Daalen, 2008). For a broader overview of transition models see Holz (2011), Safarzynska et al., (2011), Safarzynska and van den Bergh (2010) and a special issue on computational and mathematical approaches to societal transitions (Timmermans and de Haan, 2008).

Since the MLP has not received analysis with a formal model there is no assessment of whether the necessary causal factors it postulates are sufficient in order to generate the typical transition dynamics as described in its typology. The construction of a formal model based on a theoretical framework that is derived from concrete cases will make its assumptions credible and allow for an exploration of their implications. This could result in improvements in the theory so as to assure strong internal validity (Davies et al., 2007). Consequently, the work presented in this paper may be of interest to the community of researchers using the MLP, even when they are not using formal models themselves. 
The modelling approach used is system dynamics. This choice is motivated by the fact that sociotechnical transitions theories, notably MLP, involve multiple and interacting dynamic processes, time delays, and non-linear effects, such as feedback loops and thresholds. System dynamics is suitable for understanding the behaviour of dynamic systems that exhibit these characteristics (Sterman, 2000).

The emphasis of this study is on evaluating how well the model portrays a particular MLP transition pathway, namely regime substitution, by making explicit the links between the functioning of the regime's social groups and the timing of changes that unfold in a complete substitution process. While these are described in theory and in transition cases, the model enables simulating the forces and the actors in the system and tracing the consequences of their actions over time. In this way, it is possible to test, at least in part, the assumptions under which a substitution pathway can actually take place and whether modelling results are consistent with qualitative descriptions from MLP theory.

The choice of the substitution pathway was based on three considerations. First, developing a model of a specific MLP pathway rather than a generic MLP model may be regarded as a logical and prudent first step. Prior attempts to develop a generic model of the MLP (Bergman et al., 2008) were successful to some extent, but the modellers admitted that they had to reconfigure the model each time in order to reproduce all transition pathways, meaning that they did not really achieve an entirely generic MLP model. In view of this, it was decided that model development in this paper should focus on a single transition pathway. This could result in a consistent, in-depth modelling study of an important pathway. Moreover, it might ultimately contribute to a broader perspective on MLP and allow for identifying essential differences between transition types, that is, once models of other transition pathways would have been developed. In other words, this study is part of a larger, ambitious research line.

A second consideration for choosing the substitution pathway was that it could be broadly conceptualised and understood in terms of feedback loops and a discontinuity between the old and new sociotechnical regimes, and the niche. This could then be modelled following the approach of system dynamics, namely as shifting feedback loops. The de-alignment/re-alignment pathway was considered but not chosen, despite the fact that it involves similar feedback, because it would involve anticipation of de-alignment/re-alignment processes in all of the regime's elements. This would imply a much more complex model.

A final consideration was that the substitution pathway was expected to allow for clear interpretations of model results. This would help to validate the model. 
The remainder of the paper is structured as follows. Section 2 offers a brief overview of the Multi Level Perspective (MLP). Section 3 discusses how the substitution pathway dynamics were implemented in the model. Section 4 presents the validation tests with the model and develops the scenarios that were simulated. Section 5 presents the results of numerical simulations. Section 6 concludes.

\section{The MLP Framework and Transition Pathways}

The Multi Level Perspective (MLP) is a framework for studying (radical) technological change and diffusion. It emphasizes the role of social (group or network) interconnections and dynamics in system change and inertia. System developments are conceptualised as taking place at three levels that include the elements necessary for fulfilling a societal need. They are the outcome of the activities of actors who are embedded in interdependent social groups each with their own set of rules (Geels, 2004). It follows that intergroup coordination and alignment of activities is important. This coordination takes place on a meta-level of the sociotechnical regime. This is a broadened version of Nelson and Winter's (1982) technological regime, that apart from shared engineering and cognitive rules includes scientists, policy makers, users and special-interest groups (Geels and Schot, 2007). Consequently the stability and change of a sociotechnical system is the result of these interactions between multiple social groups. Tensions and mis-matches among activities of different groups can lead to misalignment of rules and create space for change.

The relationship between the three levels of the MLP is conceptualised as follows (Geels, 2002): (i) the landscape at the macro level, which forms the exogenous environment, and through its influence on the sociotechnical regime, it makes certain developments in it easier than others, (ii) the established sociotechnical regime level where incremental technological developments take place that constitute the trajectory of the regime, and (iii) the niche level where radical innovations incubate and proliferate. According to Geels (2004) a socio-technical regime comprises three interrelated elements: (i) a network of actors and social groups, (ii) formal, cognitive, and normative rules that guide the activities of actors, and (iii) material and technical elements, such as artefacts and infrastructures.

Actors and groups influence the trajectory of technology development by adhering to a set of rules that guide their activities. Consequently, the progression of a sociotechnical regime is quasi-(co)evolutionary as many engineers in the production part of the system anticipate, in different ways, the changing needs of many users and the wider selection environment. This reciprocal interaction guides the search heuristics of engineers, rendering them in effect blind to developments outside their focus (Nelson and Winter, 1982), to regulations and standards (Unruh, 2000), to socio-cultural adaptation to technical systems, to sunk investments in machines and infrastructures, and to competencies (Christensen, 1997). 
Hence, the stability of the sociotechnical regime influences, but also stems from, technological trajectories. This is part of the reason for the resistance that innovations from niches face in breaking through. They can overcome such resistance if the regime is destabilised, either internally or through landscape pressure, by taking advantage of ensuing "windows of opportunity".

The regime's response to destabilization can be such as to accommodate the landscape pressures and absorb the innovations developed in niches. If this is not possible, it can, under certain conditions, cause a transition to a new regime. In this case, the dynamics and pace of the transition are modulated by the selection environment in which the system exists. In general, this consists of the group of consumers and the institutional framework which includes a regulative, a cognitive and a normative component (Scott, 2008). In the MLP transition typology there are four transition pathways and each one is characterised in terms of the nature and timing of the interactions among the landscape, regime and niche levels (Geels and Schot, 2007).

Landscape pressures and regime dynamics can modulate niche development by creating windows of opportunity, and eventually contribute to niche success or failure. Whether a niche is sufficiently developed in order to become a candidate for an alternative to the incumbent regime is a matter of qualitative assessment based on four criteria (Geels and Schot, 2007): (i) the emergence of a dominant design, (ii) the enlargement of the network of actors, (iii) improvements in the price/performance ratio, and (iv) a cumulative market share of more than $5 \%$ for the new technology. Finally, a transition ends when a new socio-technical regime has emerged, meaning that the social and technical aspects of innovations and their use become embedded in the institutional, the production and the user subsystems of the sociotechnical system.

\section{Modelling the Substitution Pathway}

The model focuses on the substitution pathway and the necessary and the causal mechanisms necessary for reproducing a complete substitution. Hence, it is assumed a priori that the regime lacks the endogenous capacity to respond to the contingency of pressures and persistent problems it faces. The model illustrates the interplay between endogenous feedback processes and contextual, situational factors that determine the dynamics of a substitution transition. Initially the regime is in the reproduction pathway, then it goes through substitution and finally returns to reproduction. It should be noted that there are no case studies of sequential transitions of the same system and consequently such a possibility has not been considered here or in any of the models so far. 
Geels and Schot (2007) describe the conditions under which a technological substitution can take place. For this to happen, there has to be some form of significant landscape pressure and at the same time innovations in niches have to be sufficiently developed. Pressures on the regime destabilise it, create misalignment of actor activities and open windows of opportunity for niche innovations to break through.

However, even when niche innovations succeed in entering the market, they can still face resistance from regime actors who invest in improvements of the incumbent technology. Market competition and power struggles influence the eventual outcome of the interaction between incumbents and outsiders. If the innovation replaces the old technology, this has wider consequences, and influences the entire system (see the case in Geels, 2002).

The following sections outline the assumptions and choices that were made in creating the model representation of the sociotechnical regime, the niche, their interaction and the way a transition unfolds.

\subsection{The Regime}

In order to simplify the modelling task, certain assumptions concerning the level of detail of the model have been made. Figure 1 shows the main elements of the model which includes social groups, and the resources they utilize in order to perform their function and in doing so reproduce the sociotechnical regime. Thus it is a combination of Figures 1 and 2 in Geels (2004). For example, the element of users/consumers is taken to represent the regime of markets and user preferences. Industry production attributes includes the technical characteristics of the technology utilised such as efficiency, price and scale of production. Figure 1 is a high level representation of the model, and is meant to convey the core logic, which is that agents utilise resources in order to supply a function. The complete model includes both a production and a user side and its structure is related to all of the relevant actors detailed in Geels (2004), both for the old and new sociotechnical regimes. The policy making apparatus is taken to represent the public authorities, ministries and executive branches that are involved in governance. 


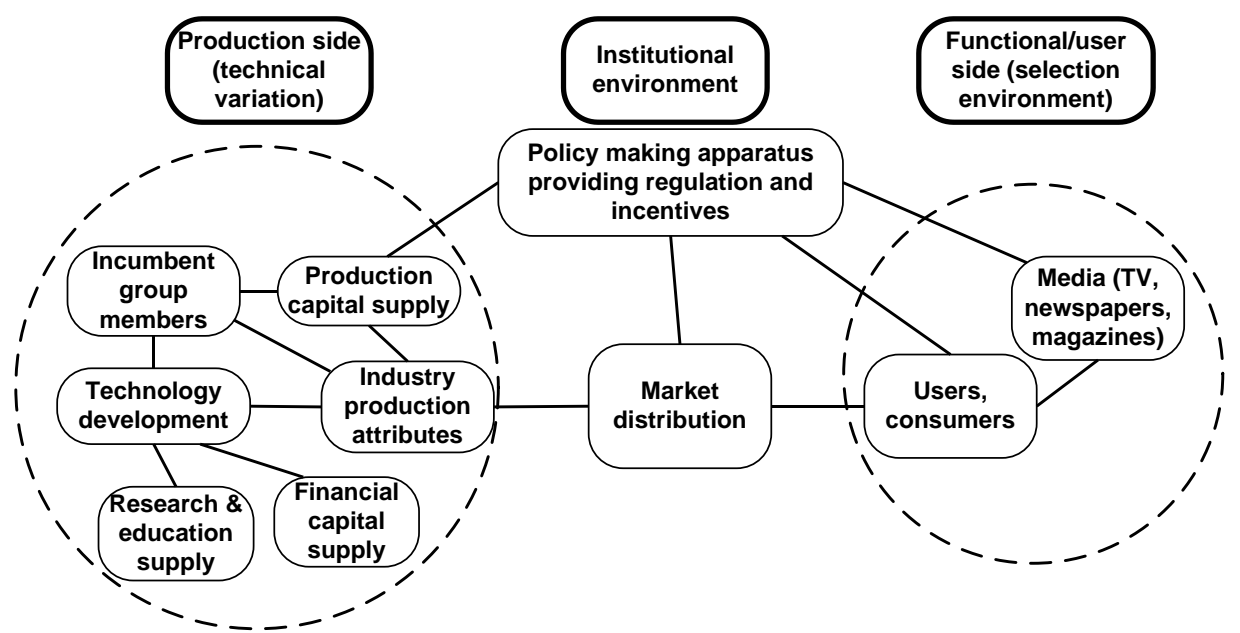

Figure 1. Social groups and resources involved in regime reproduction, as applied in the model.

The links between the model elements are bidirectional and represent the interactions that take place and generate the dynamics of the system. These links are maintained and reproduced as long as there is alignment and coordination of activities in the system. Figure 2 shows the general dynamic logic that the sociotechnical regime follows. Arrows show how one process drives another. For example, the activities of the social groups create an environmental effect at the landscape level. It increases cumulatively and along with other landscape pressures generates problems that are perceived as persistent. They inevitably lead to a search for a new sociotechnical trajectory, a process that generates an adaptive response from the regime by realigning some of the internal processes and activities. The alignment of activities stems from networks of actors and resources, capable of altering both the sociotechnical regime alignment and the niche dynamics. The regime response process involves both inertia and system resistance. Inertia comes in the form of infrastructure being already in place and system resistance is described by Incumbent resistance (variable names in italics). This represents the unwillingness of Old regime members to contribute to, and their active opposition to policies aiming to bring about, change. Broadly, the model logic is that of a stimulus-adaptive system response relationship. In the substitution pathway the inability of the regime to generate an adequate adaptive response results in its eventual replacement. This process has been modelled with distinct model subsystems for the old and new sociotechnical regimes and the niche. 


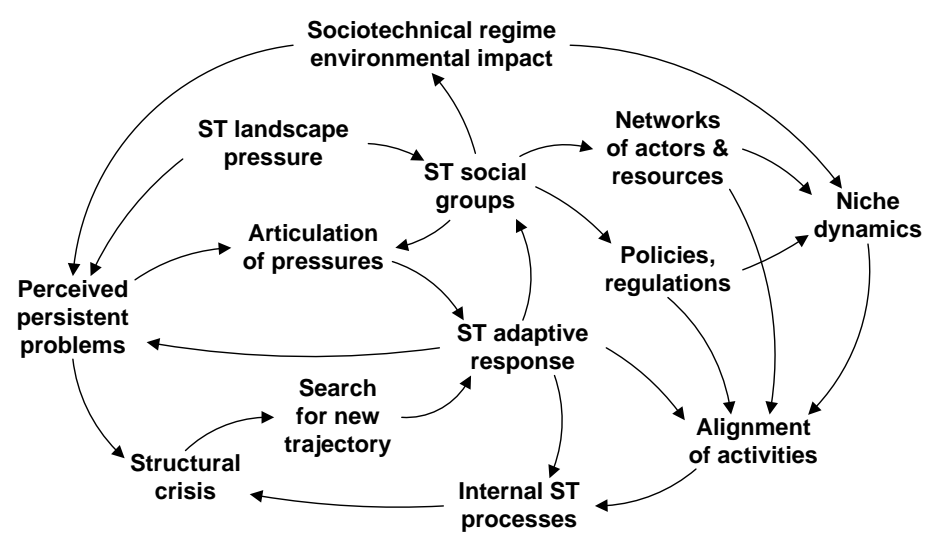

Figure 2. High level representation of the sociotechnical regime

\subsection{Niches}

The niche part of the model is based on the idea that technological niches and sociotechnical regimes are similar kinds of structures, although different in size and stability (Geels and Schot, 2007). Consequently, the niche module includes variables for Niche Users and Niche Production Capacity, Niche R\&D, Technology Expectations and Regulation - Incentives that contribute to protecting the niche (technological or market) but no variables for established rules or alignment of activities. As a sociotechnical regime consists of a range of technology niches, evaluation of alternative technologies is necessary. This is based on Technology Performance and Technology Price that comes down with Cumulative Production. Figure 3 offers an aggregate conceptual view of how the internal niche dynamics have been implemented in the model. As regime users become gradually aware of the regime's effect on the environment, the need for a new technology arises. This leads to competitive allocation of financial capital (FC Capital) to candidate technologies based on Technology Expectations Fulfilment.

Technological niches are protected by actors willing to invest time and money in them. It is assumed that government involvement is high in the initial stages, until an internal self sustained flow of capital is established. Niche processes become self-sustaining gradually as production capacity and revenue for each technology increase. The flow of capital into the niche does not cease, however, reflecting its protective character. The reason why actors are assumed to protect non-competitive innovations is the perceived importance of realizing societal and collective aims (Schot and Geels, 2007), which in the context of the model are related to societal issues (conservation, efficiency and sustainability), and expectations that the innovation will become viable in the future. Thus the work on niches is guided by an expectation of future improvement of technological performance and perceived threats caused by environmental degradation or market opportunities. It is through processes of incremental change within each niche and competition between them that a candidate new sociotechnical regime emerges. 
Learning about new technologies in the niche takes place with Cumulative Production and this can alter the eventual outcome of the technological competition in the niche, as technology performance improvement through $R \& D$ is stochastic. This is done in order to represent the intrinsic path-dependent nature of technology $R \& D$ (Arthur, 1989) but also the lack of clear and stable rules to guide the search heuristics of engineers (Schot and Geels, 2007).

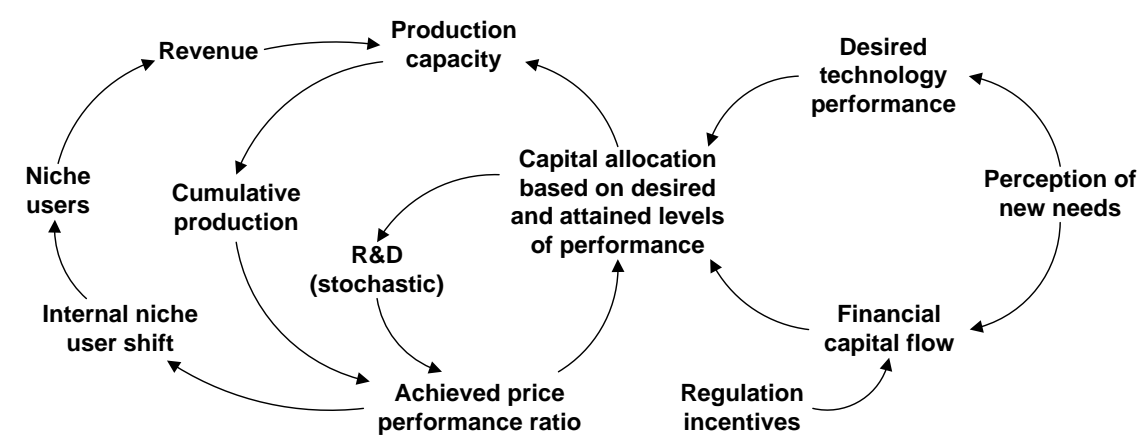

Figure 3. High level representation of the niche

The four criteria for the viability of a niche are included in the model. Consequently, once a technology becomes dominant and exceeds the 5\% market share threshold proposed in Geels and Schot (2007), then a percentage of the technology and related level of performance (0-100\%) can be transferred to the regime (see Figure 4 below). This reflects the fact that further constraints in the regime might not make possible the full exploitation of technologies developed in niches. An example from the automobile regime is the partial transfer of race car (e.g., Formula 1) technology to every day use. Racing acts as an incubation space out of which certain applications arise, such as Continuously Variable Transmission systems (CVT), which then are transferred and used in commercial cars.

\subsection{Niche-Regime Interaction}

Figure 4 displays the interaction between the ST regime and niche. New Regime Science develops as a result of observing the socially undesirable effects of the regime and is utilised in R\&D in the niche. The Perception of New Needs and the Perception of Regime Effect, drive the Desired Technology Performance levels of the niche technologies. The latter is assumed to drive the Awareness Shift of the Old Regime Aware Users some of which eventually enter the niche. Regulation - Incentives is used to create the protected technology space in which the new innovations can flourish. This is done in two ways. First, it is used to enhance the price performance ratio of niche technologies, and second to induce users into the niche and stimulate funding of R\&D activities. The Window of Opportunity, influenced by Political Pressure from the users who are aware of the regime's environmental impact and their new needs, further stimulates them to move into the niche. I have chosen to represent the drivers of R\&D in the niche as Financial Capital (which in turn is a function of perceived new needs), Regulation Incentives and New Regime Science that is developed as a result of the Regime's Environmental Impact. 


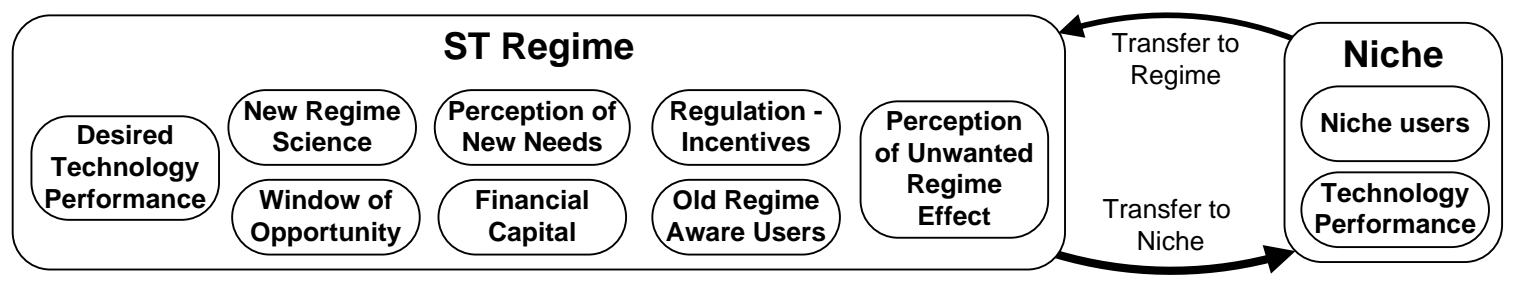

Figure 4. Sociotechnical regime - niche interaction

Old Regime Aware Users are the ones that have become aware of the Regime's Environmental Impact and enter niches. It is assumed that the value system upon which they evaluate technology changes. Subsequently, niche users grow in number, choose between alternative technologies, and set in motion processes of niche accumulation that eventually enhance the competitiveness of the innovations and bring about a shift of the remaining Old Regime Aware Users to New Regime Users (Figure 5). The Technology Performance of candidate innovations developed in the niches is transferred in whole or in part in the new regime as the transition is completed (the percentage of transfer can be set prior to running a simulation). Figure 5 illustrates the transition that takes place in the users/consumers group of the sociotechnical regime (see Figure 1). Thus, users choose twice, first on the basis of values prior to entering a niche and then on the basis of technology performance.

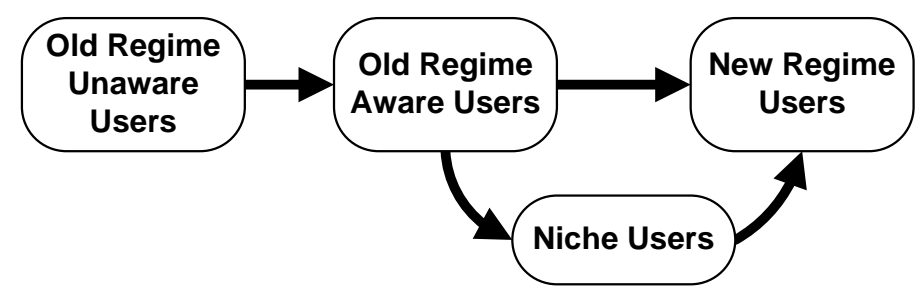

Figure 5. Schematic representation of user transition in the model

\subsection{Alignment of Activities}

Alignment is an important concept in the MLP as it influences the stability of the regime. Pressures that act on the regime reduce the alignment among the activities of its social groups. Alignment can also decrease as new groups associated with the new regime become active. As the transition is completed it is eventually restored to its original value. The generic way in which the alignment between groups and activities has been conceptualised is shown in Figure 6. For example, group 1 may be associated with production activities of the incumbent regime and group 2 with those of the candidate niche. Assuming that the activities of the niche $\left(A_{n}\right)$ are competitive to that of the regime $\left(A_{r}\right)$, the degree of alignment is calculated as $\max \left(\mathrm{A}_{\mathrm{n}}, \mathrm{A}_{\mathrm{r}}\right) /\left(\mathrm{A}_{\mathrm{n}}+\mathrm{A}_{\mathrm{r}}\right)$. 


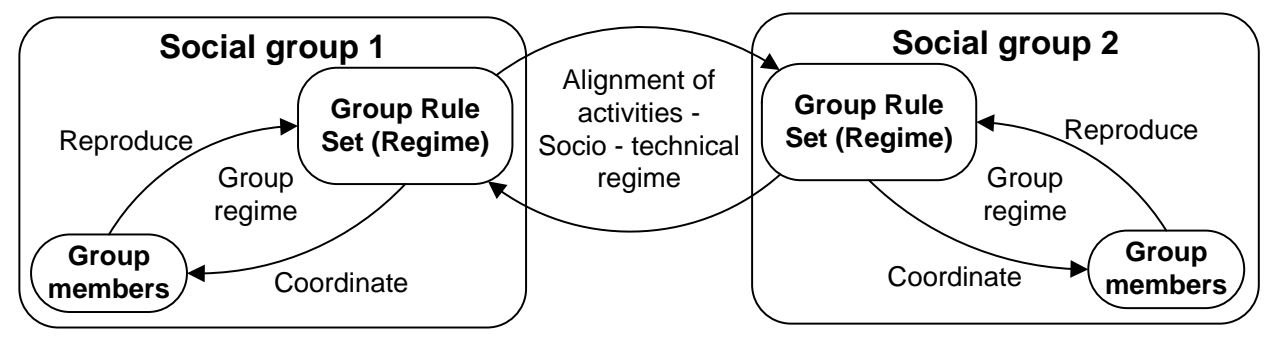

Figure 6. Alignment of activities in the regime

The overall regime alignment is taken to be the average of the Production Capacity Alignment, Production Capital Alignment, Rule System Alignment, Regime Member Alignment and Production Resources Alignment. It is also depends on the Window of Opportunity created by landscape pressures that drive the public perception of new needs and political pressure for change. It is assumed that at least some regime actors perceive this window as an opportunity to deviate from established practices and steer their activities accordingly. Finally it depends on science (Science Alignment). If the environmental effect of the incumbent regime is perceived as unwanted then this is due partly to the way scientific activity is pursued and applied, and how its results are disseminated.

\section{Validation and Testing}

The case studies of socio-technical transitions available in the literature offer limited numerical data The available data are primarily qualitative, historical and anecdotal. In the light of this, the parameter values used in the model reflect stylized facts or are conjectural. However, as the focus is on pattern reproduction and not on reproducing a specific case study, the results are of value particularly in illustrating how delays in processes of the system influence its behaviour.

Sensitivity tests have been performed, both on the delay constants and the equations used in variables.. Large variations in initial conditions and/or variables cause the model's behaviour to vary. However the qualitative behaviour of the model does not change and, the pattern of behaviour the model exhibits is maintained (see results section). This provides evidence for validity of model behaviour and its results which will be reported in the next section. Thus the significant uncertainty surrounding numerical values does not constrain the use of the model as a theory testing tool (Sterman and Wittenberg, 1999).

Due to model size (491 variables, 275 equations), a full presentation of the sensitivity tests that have been conducted would require considerable space which is not available here. Instead, three scenarios were formulated by varying the regime's impact and the delays of the system. Values have been assigned to constants in such a way that the best case scenario represents a situation characterized by a small regime impact and the delays in the system are small. The worst case represents a situation with a large regime effect and long delays. Keeping the pattern of stochastic R\&D processes identical allowed 
for isolating the effect of delays in the system. Testing for these scenarios was expected to result for the best case scenario in an early transition and for the worse case scenario in a delayed transition relative to the reference simulation. The scenario set-up is shown in Table 1 below.

Table 1. Scenarios and constants.

\begin{tabular}{|l|c|c|c|}
\hline \multicolumn{1}{|c|}{ Constant } & Reference & Best case & Worst case \\
\hline $\begin{array}{l}\text { Initial old regime environmental effect } \\
\text { (unitless) }\end{array}$ & 2000 & 1000 & 3000 \\
\hline Window of opportunity open delay & 10 years & 5 years & 15 years \\
\hline Time to develop production capacity & 10 years & 5 years & 15 years \\
\hline Delay in regulation effects & 15 years & 5 years & 15 years \\
\hline Delay in user transition & 5 years & 2 years & 7 years \\
\hline Regime effect perception delay time & 40 years & 30 years & 50 years \\
\hline Political pressure change delay time & 5 years & 2 years & 7 years \\
\hline $\begin{array}{l}\text { Time for production capacity } \\
\text { depreciation }\end{array}$ & 10 years & 10 years & 10 years \\
\hline Time to train in current paradigm & 5 years & 5 years & 5 years \\
\hline Efficiency improvement delay & 3 years & 2 years & 4 years \\
\hline Delay in environmental impact & 20 years & 10 years & 30 years \\
\hline Need perception delay time & 10 years & 5 years & 15 years \\
\hline Time to train in new paradigm & 5 years & 3 years & 6 years \\
\hline Time to retrain in new paradigm & 10 years & 7 years & 15 years \\
\hline Observational delay of regime effect & 5 years & 5 years & 10 years \\
\hline
\end{tabular}

Further tests were carried out in order to identify conditions under which a complete transition will not take place. The following table presents a list of tests carried out with the model in order to assess the model's behavioural validity. For example, testing with a zero initial environmental effect results in a delayed transition and testing with no effect results in no transition, as expected.

Table 2. Behaviour tests carried out with the model

\begin{tabular}{|c|c|}
\hline Test & Behaviour \\
\hline Zero initial regime environmental effect & Delayed transition \\
\hline $\begin{array}{l}\text { Zero initial regime environmental effect \& } \\
\text { zero regime environmental effect rate }\end{array}$ & No transition \\
\hline $\begin{array}{l}\text { Zero user perception of the regime's } \\
\text { environmental effect }\end{array}$ & No transition \\
\hline No political pressure for changes & No transition \\
\hline $\begin{array}{l}\text { No scientific observation of regime } \\
\text { environmental effect }\end{array}$ & $\begin{array}{c}\text { No transition because there is no awareness } \\
\text { shift. }\end{array}$ \\
\hline $\begin{array}{l}\text { No regulation, no incentives for development } \\
\text { of alternative technologies }\end{array}$ & Users awareness transition \\
\hline No change in rule alignment $\&$ stability & $\begin{array}{c}\text { Users become aware of regime environmental } \\
\text { effect }\end{array}$ \\
\hline No regime membership change & No transition \\
\hline No entrance of new members to the regime & Complete transition \\
\hline $\begin{array}{l}\text { Niche technologies of equal development } \\
\text { potential (see Figure 12) }\end{array}$ & Delayed process of transition \\
\hline
\end{tabular}




\section{Results of Model Simulations}

Here the results of the simulations are presented. While there are numerous variables of interest in the model, the focus is on those which correspond most closely with the theoretical concepts of the MLP. Figures $7-13$ illustrate the behaviour of model variables over time (horizontal axis in years) for the reference, best and worst case scenarios.

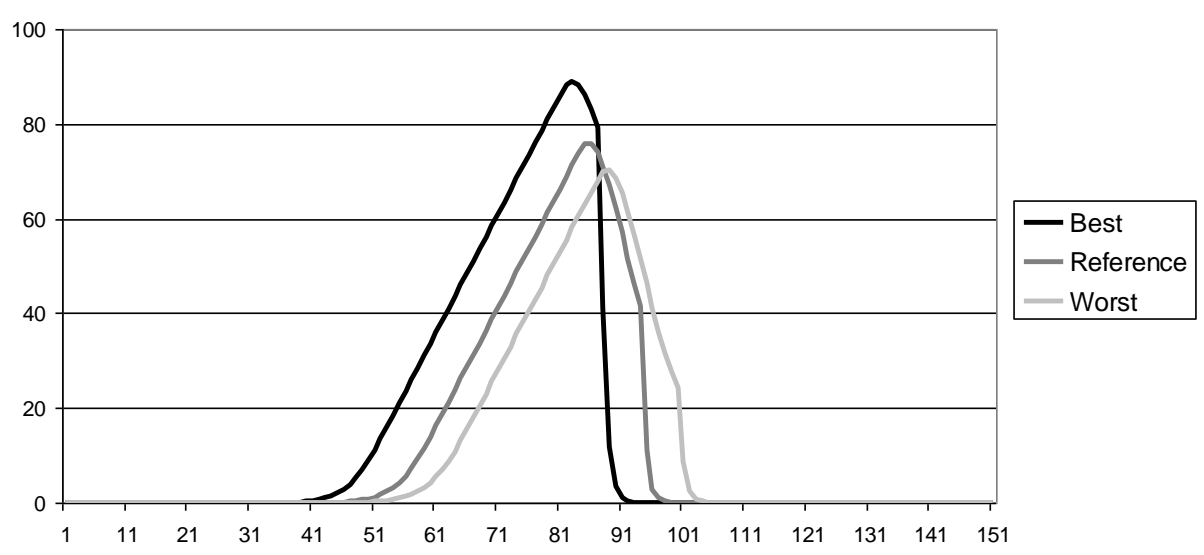

Figure 7. Users of niche technologies over time

In the best case scenario, the niche starts developing approximately 15 years earlier and peaks higher at $9 \%$ of the total users of the system (note: $\mathrm{y}$ axis in figure 7 is $0-100$ users for illustration purposes while total system users is 1000). What is of interest is the relative magnitude and timing between the scenarios. It is worth noting that one of the conditions for the viability of the niche postulated by Geels and Schot (2007) is that niche users make up about $5 \%$ of the total market share, a threshold which is consistently exceeded in all three scenarios.

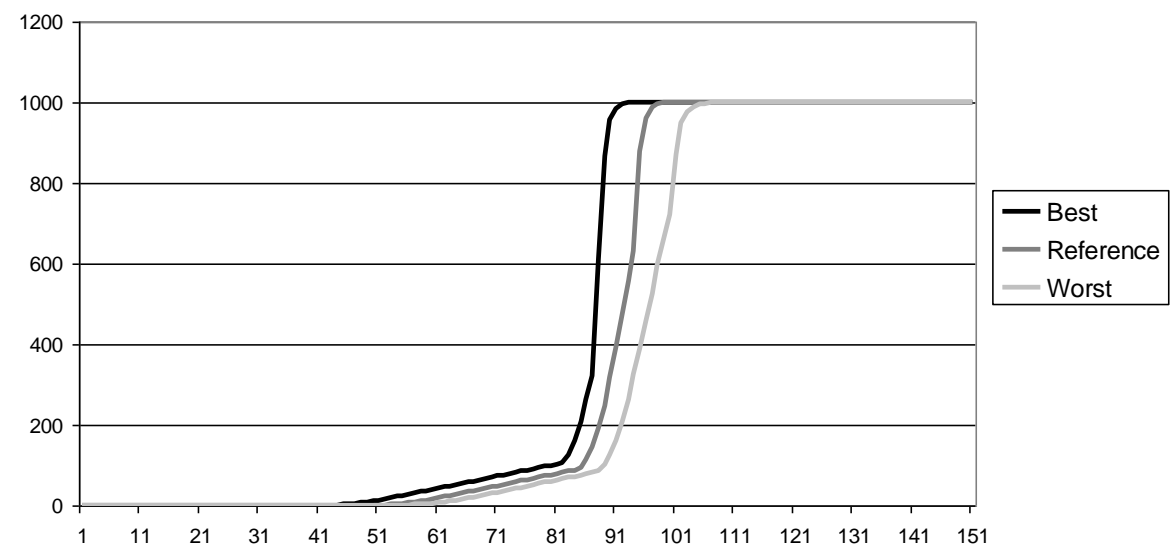

Figure 8. Total new regime users plot

In the best scenario the system undergoes a transition about twenty years earlier than in the latter case (Figure 8). In all three scenarios the general pattern of technology adoption among users is similar despite the fact that delays in the worst case scenario are double that of the best case scenario (see table 1). In effect, changing the delays does not change the way the dominant loops operate in the model. As 
expected, the production capacity behaviour follows the trends of the users closely (Figures 9, 10, 11, 12).

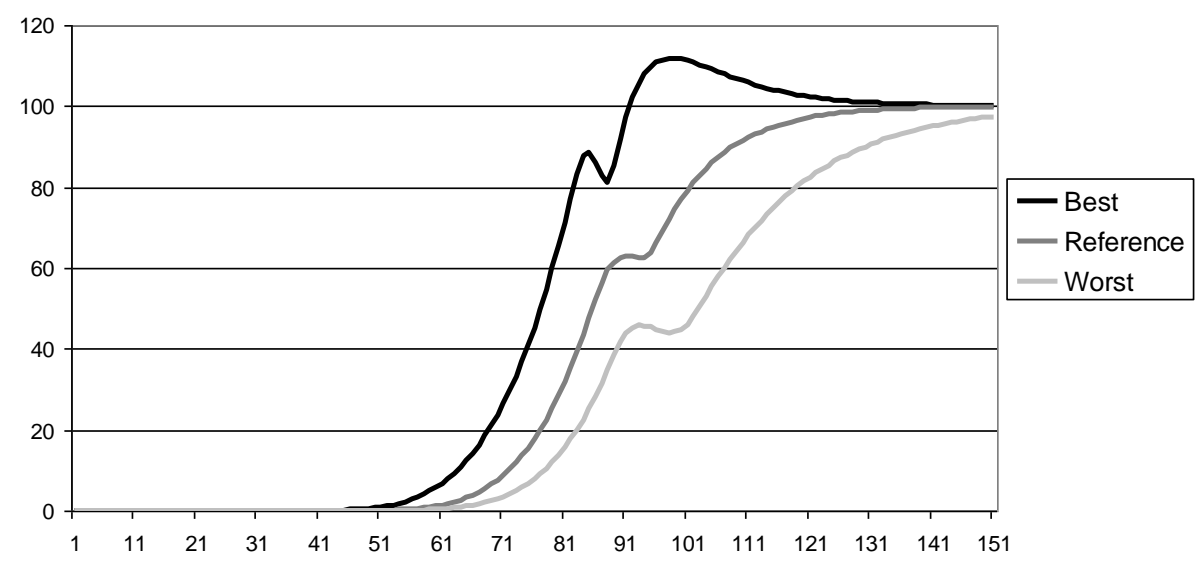

Figure 9. Total new regime production capacity plot

The total new capacity in the model (y axis in Figure 9) is the sum of the capacity in all three candidate niches (Figure 10) and the new regime (Figure 12). The difference in behaviour is observed because in the best case scenario, the delays in the system allow capacity to build up quickly before capacity in the niches, which peaks in years 82-92, depreciates. Furthermore, in the best case scenarios capacity exceeds 100 , which is the required capacity for supplying the user population demand. An explanation for this is that competition among the technologies in niches builds capacity which eventually is removed, with some delay, when users move to the new regime. This is what creates some temporary overcapacity in the system. This is a phenomenon that has been documented in transition studies (Verbong and Geels, 2007) and is also present in the history of electronics and micro chips (Brown and Linden, 2009).

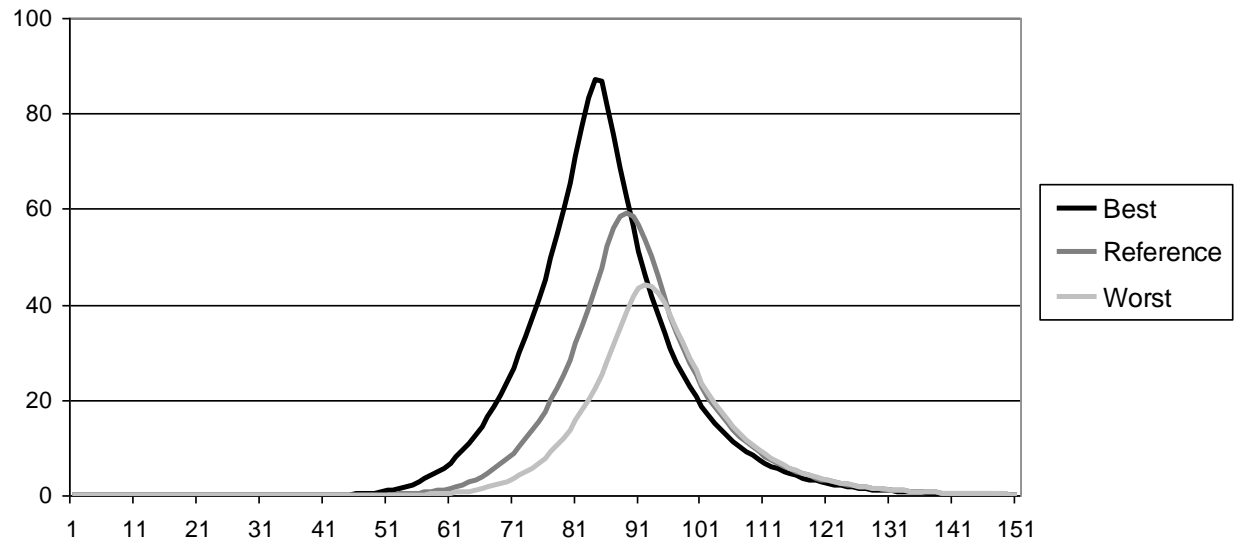

Figure 10. Total niche production capacity

The total capacity in the system (old and new regime and niches) available at any moment to supply user needs is shown in Figure 11. The difference is that in the best scenario the system does not enter a state 
of under-capacity as the system responds quickly and builds new capacity. In the worst scenario the system experiences the most severe under capacity. This can be explained by looking at Figure 12 which shows the production capacity of the new and old regimes. This behaviour holds in general for any damped control system. All other things being equal, the more rapid the response to a stimulus is, the less time it takes to come to rest. Note that while capacity starts to increase earlier in the best case, the system comes to equilibrium at approximately the same time under the reference scenario.

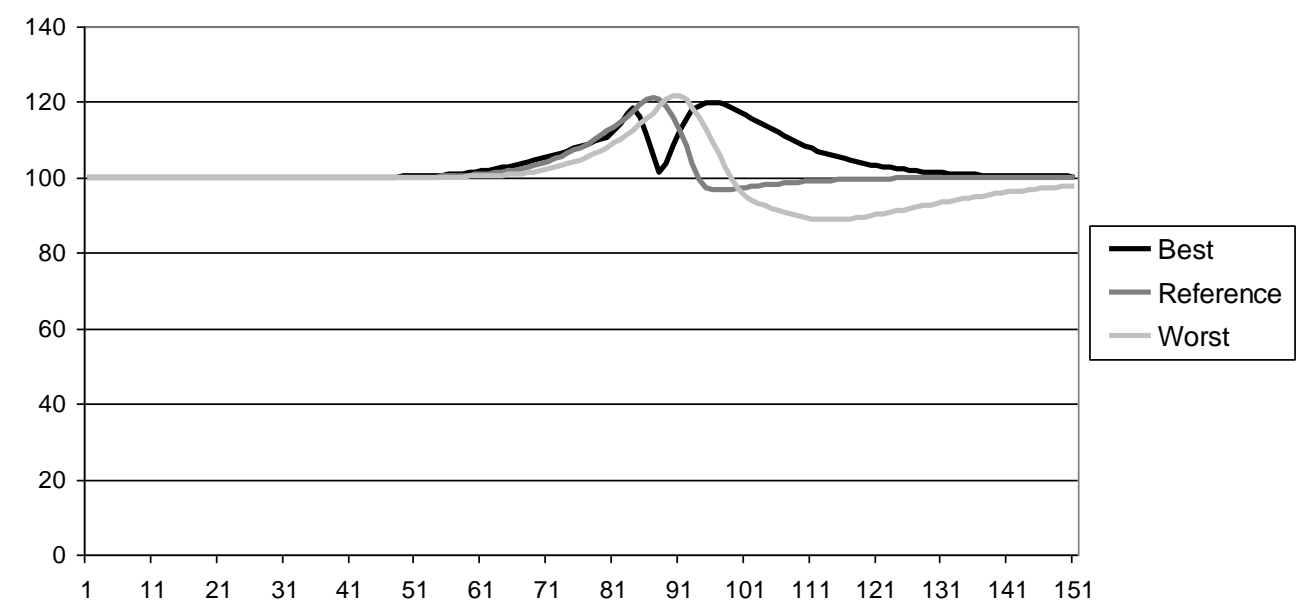

Figure 11. Total system capacity plot (old, new regime \& niche)

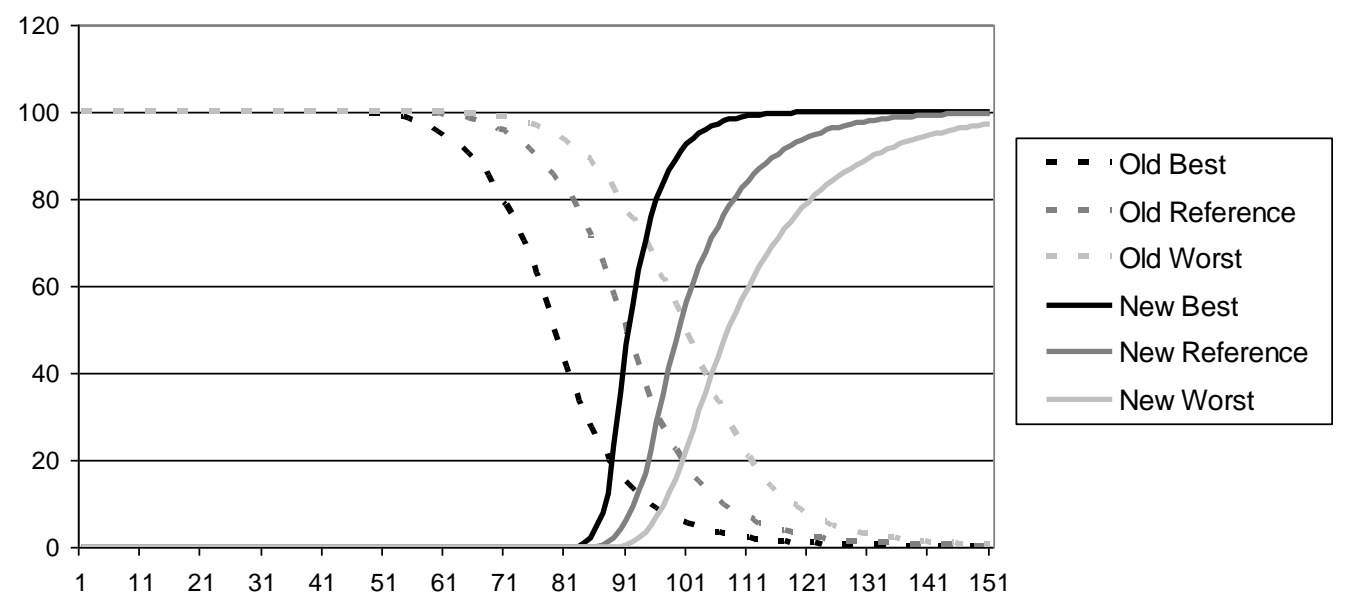

Figure 12. Regime capacity transition

Figure 13 shows a what-if scenario where the model is set to reference scenario but with the added complication that technologies developing in the niches have the same development potential, resulting in no clear substitute to emerge. Because of the increased uncertainty, actors hesitate to commit to niche alternatives and technology development is delayed. The behaviour illustrated in Figure 13 is logical in this sense as this is a typical mechanism (although not the only one) ${ }^{1}$ in systems undergoing a transition. It shows the possibility of delay in system transition if competition between innovations is prolonged or if more than one innovation is adopted.

${ }^{1}$ I would like to thank one of the reviewers for pointing this out. 


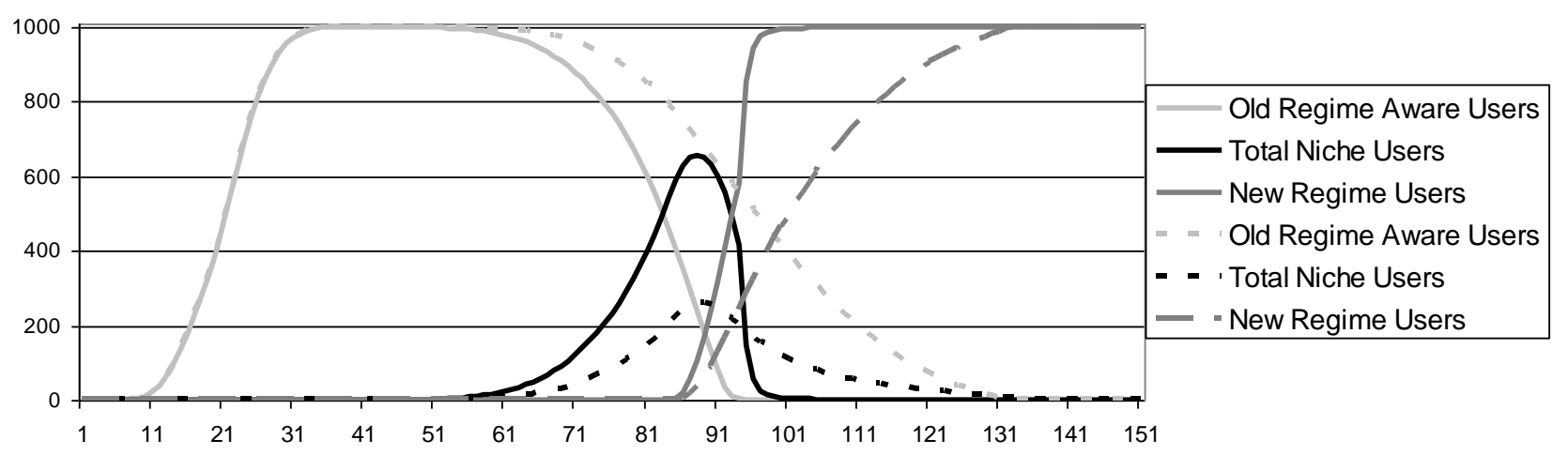

Figure 13. Comparison of user transitions between the reference and equipotential niche technologies scenarios

As this model was not based on a concrete historical case study against which it can be validated, deriving as much output as possible from the model was desirable for two reasons. First, to provide evidence for its validity. Second, as the model is of medium size (491 variables, 275 equations, see Appendix), there are numerous variables that can be plotted with time, each revealing some aspect of the transition process. The framework of Smith et al. (2005, Figure 1) provides another way for visualising a transition process in terms of the locus of resources and the alignment - coordination of activities. They define four transition contexts in terms of which a transition process can be analysed. Model output in Figure 14 shows the trajectory of the simulated reference scenario.

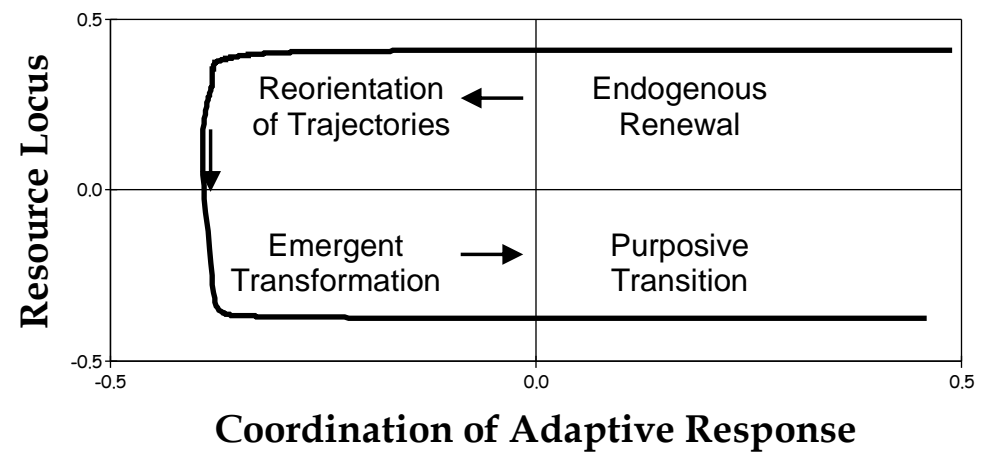

Figure 14. Transition trace in terms of transition framework of Smith et al. (2005)

The trajectory of the model starts on the top right, in the renewal mode and proceeds to reorientation of trajectories, a state in which solutions to the persistent problems are sought within the regime members and resources. However, in the substitution pathway the regime is unable to generate an endogenous response to landscape pressures causing its coordination to break down. In response, technologies that have emerged in niches are assessed in order to arrive at a substitute. Resources and capabilities situated outside the incumbent regime are required to generate a response to the persistent problems the regime faces. Subsequently the trajectory moves to the third quadrant of emergent transformation. The interpretation of this is that the incumbent regime contributes some of its resources to the new regime 
while the rest is left to depreciate and disappear. At this point there is no way to distinguish the niche that will become dominant since niche R\&D is stochastic. Finally as the coordination among the members of the new regime increases the process enters its purposive phase where all of the resources of the new regime and its activities gradually become aligned.

Plotting the time the system spends in each quarter (Figure 15) provides some relevant information for governance. What is required is a swift assessment of whether the regime can endogenously generate an appropriate response to the pressures it is subject to. The aim is to avoid "muddling through" the reorientation of trajectories which takes up considerable time, and instead move quickly to the emergent transformation phase where viable solutions can be found. Figure 16 shows a comparison of the best and worst case scenarios simulated in which the cumulative build up of delays at the end of the transition is illustrated.

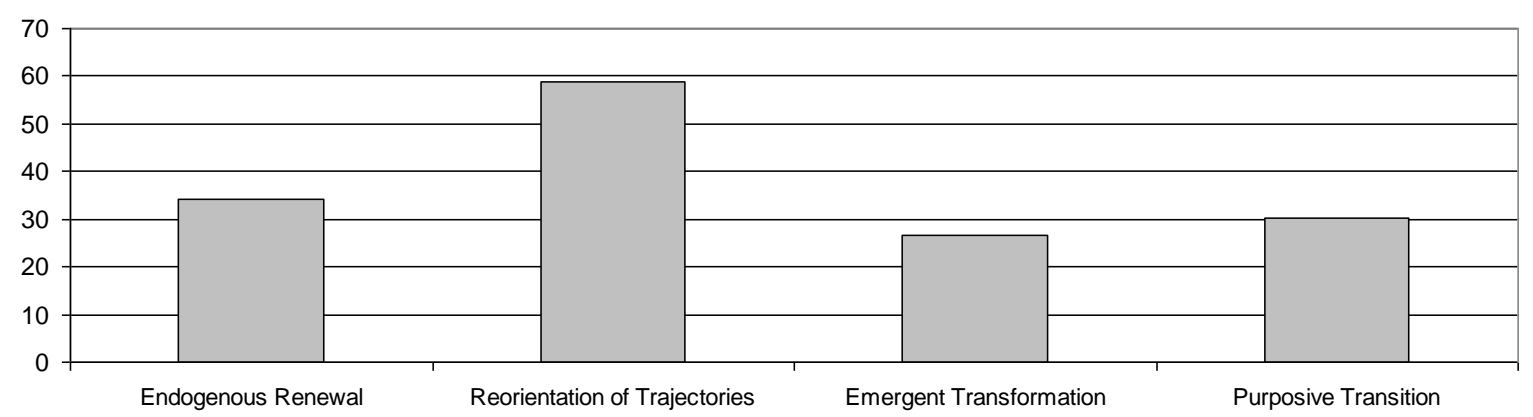

Figure 15. Amount of time the sociotechnical systems spends in each transition contexts

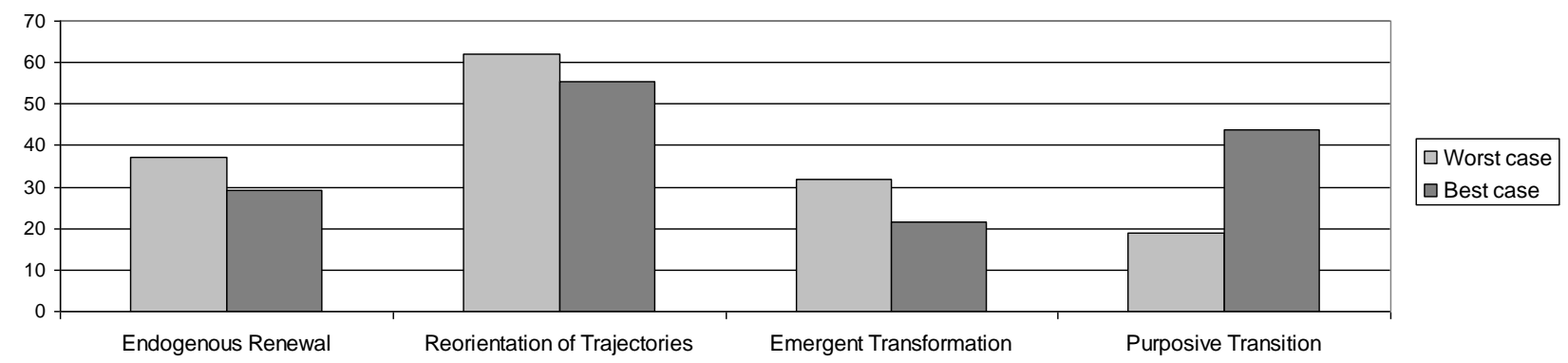

Figure 16. Comparison of the time the system the spends in each transition context in best and worst cases

Looking again at the descriptions of types of transition pathways it is possible to split them in two sets, assuming that the break-up of alignment and coordination of activities of social groups results in the break-up of system organization. The breakdown of organization is used here in the same sense as it is used in autopoiesis theory (Maturana and Varela, 1980) to denote the end of the autopoiesis process that sustains the living organism (in this case the equivalent entity is the sociotechnical system). Hence, the first set includes the reconfiguration and transformation pathways, while the second includes the substitution and de-alignment realignment pathways. In this way an idealized substitution trajectory is shown in Figure 17: 


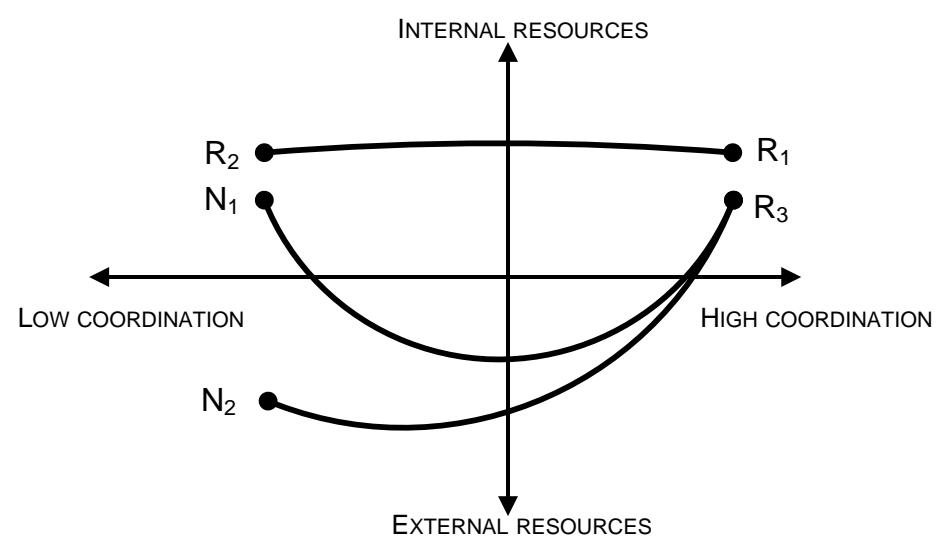

Figure 17. Conceptualized trajectory of the substitution pathway

Here the established sociotechnical regime's trajectory $\left(\mathrm{R}_{1}-\mathrm{R}_{2}\right)$ represents the decrease in coordination and eventually the break up of the system's organization. The two trajectories $N_{1}-R_{3}$ and $N_{2}-R_{3}$ represent different possibilities where niches using resources found within the established regime $\left(\mathrm{N}_{1}\right)$ or outside of it $\left(\mathrm{N}_{2}\right)$, develop into a new regime $\left(\mathrm{R}_{3}\right)$ that substitutes the established one $\left(\mathrm{R}_{1}\right)$. Consequently solutions can be developed in internal regime niches utilising resources and competencies of outsiders (Van de Poel, 2000) or in external niches outside of the focal regime that eventually come to substitute it. This is an issue that could be looked at in more detail in future modelling studies.

Further output from the model provides food for thought. It was possible to compare model output with Figure 2 in Schot and Geels (2007). This provided a further test of model validity as this particular study was not taken into account during model development and thus allows for an additional validity test. Comparison of the two patterns (Figure 18) is possible because each deals with market niches characterized by some form of cognitive and social isolation, and portray the replacement of the dominant ST regime.
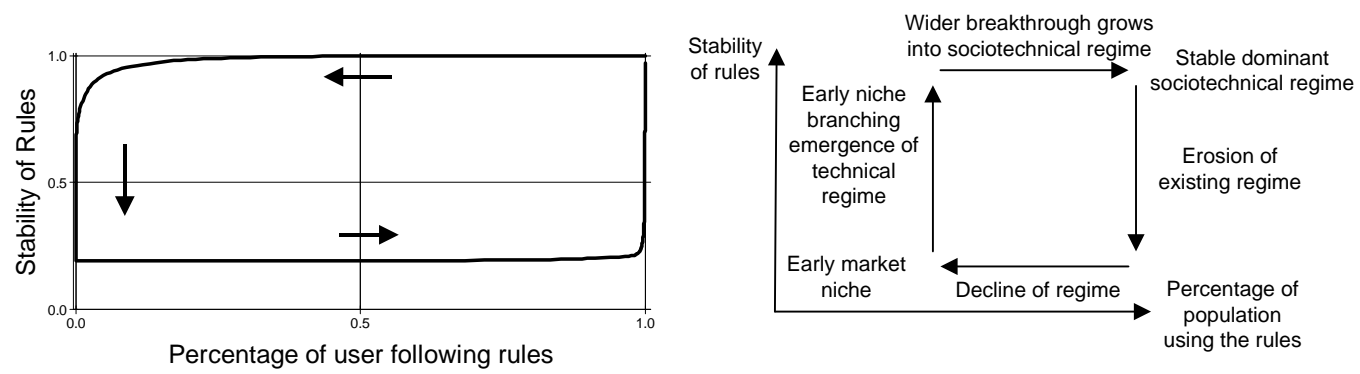

Figure 18. Emergence and breakthrough of regimes: model output (left side) compared with conceptualization by Schot and Geels, (2007, Figure 2)

The horizontal axis in both figures depicts the number of adopters that as a consequence adhere to a different rule set. The similarity of pattern is striking as is the difference of clockwise and anticlockwise 
trajectories. The two figures offer contrasting views on the same process, namely competition between the new emerging sociotechnical regime and the replacement of the prevailing dominant sociotechnical regime. Model output (left) shows the de-legitimization of rules as diminishing numbers of users adhere to them. Eventually this leads to rule erosion and instability. As the new regime emerges, increasing numbers of users follow the new set of rules, and their stability rises. The postulated figure by Schot and Geels (2007) provides a different progression of events with the erosion of the regime and the diminishing stability of rules preceding the decrease of the number of users. In the light of this, there are three possible explanations. First, that the model is wrong. However, to the extent that the results make sense, this is an unlikely explanation. Second, that the model is right but the choice of variables has produced a figure which is inconsistent with theory. Third, that the theoretical figure does not hold for the technological substitution pathway or does not hold generally. This is a point that requires more work both in terms of modelling and theory in order to arrive at solid conclusions.

\section{Conclusions}

This paper presented a system dynamics model of the substitution transition pathway of the MLP. It captures the unfolding dynamics of an existing sociotechnical regime and the emerging niches as they compete and respond to landscape pressures. In particular, it represents the dynamics of the substitution pathway. The development of new technologies in niches is endogenous and stochastic. Simulation of the model provided a partial test of the dynamic consistency of the MLP substitution pathway and raised some interesting questions and insights with regard to future modelling work on transition pathways and theory development.

Simulation results are consistent with what MLP theory suggests. Starting from causes and drivers stipulated in theory, the model produces behaviour which is consistent with the theoretical description of the specific pathway. Hence the model provides evidence for the dynamic consistency of the substitution pathway of the MLP. It shows that the behaviour of the substitution pathway as described by the MLP can be produced by the factors it postulates. In a broader sense, it illustrates how formal models can provide a complementary test for theory, even when those theories are stated in entirely qualitative abstract terms, and in a context which does not lend itself easily to explicit dynamic analysis. An unavoidable intermediate step is the choice of parameter values and the interpretation of the simulation results.

With regard to the latter, a methodological insight that this study emphasizes is the trade-off between the breadth of model scope and interpretation of model results. The model represents only the substitution pathway. Compared to the model of Bergman et al. (2008), which reproduces all five transition 
pathways of the MLP with considerable difficulties involved, there is much less room for interpretation of results because the scope of the model is narrower. In their case, in addition to model set up, structural adjustments were required in order to represent different transitions. For example, this was the case with the transition from horse-drawn carriages to automobiles. Furthermore, in discussing the results of their simulations they noted that their model captures the transition pathways but that distinguishing between the transformation and reconfiguration pathways by looking on the results is a matter of interpretation. A comparison of the model of Bergman et al (2008) with the model presented here, reveals that there is a trade-off between the scope of the model and the room for interpretation of the results. The implication of this is that future modelling attempts on transition pathways could focus on a single transition path at a time. This would then allow for comparison of different models in terms of structural similarities and differences. In this way a coherent body of knowledge can be build about transition pathways and the particular system elements and conditions that induce or inhibit them.

Further insights for future modelling can be derived from the critique of Wittenberg (1992) on Sterman's model of scientific revolutions (1985). This critique was that there is incommensurability between different science paradigms. Extending the argument in cases of complete regime substitution, there is a similar incommensurability, notably of values in a broad sense. The shift in values, belief systems, ideologies and public opinion are at the core of the transition process (Geels, 2010). This is well illustrated, for example, in the hygienic transition (Geels, 2005) and the transition from horse carriages to automobiles (Geels, 2006a). While in the current model study an effort has been made to incorporate this in Awareness Shift variable and by disaggregating users in aware and unaware categories, this is a point that should be looked at in more detail in the future. This would also involve dealing with the fact that users and producers of technology often have different priorities and as a result different assessments of technologies.

Finally, model results generate some interesting questions regarding the nature of transitions. Drawing on figures 14 and 17 two questions are worth asking. First, under which circumstances does diminishing regime coordination lead to a break-up of system organization? Is this always the case? Theory so far has looked at how ST regimes are created, transform, and adapt but not at how and when they dissolve. The second question derives from Figure 18. Looking at the evolutionary pattern of stability of rules and users adhering to regime rules, and comparing model output to theory, the question is whether and under which conditions, rule destabilisation precedes the decrease of user numbers or the order is reverse. These questions demonstrate that theory development can benefit from modelling in strengthening its internal validity and experimenting to produce novel theoretical insights. 


\section{Acknowledgements}

I would like to thank Jonathan Kohler and Jeroen van den Bergh for constructive insights and feedback, and two anonymous referees for useful comments and suggestions.

\section{References}

Arthur B., 1989. Competing technologies, increasing returns, and lock in by historical events. Economic Journal 99, p116 - 131.

Bergman, N., Haxeltine, A., Whitmarsh, L., Kohler, J., Schilperoord, M., Rotmans, J., 2008. Modelling socio technical transition patterns and pathways. Journal of Artificial Societies and Social Simulation 11(3)

Brown, C., Linden, G., 2009, Chips and change: How crisis reshapes the semiconductor industry. MTI Press, Cambridge Massachusetts

Christensen, C.M., 1997. The innovator's dilemma. Harvard Business School Press, Boston, Massachusetts.

Davis, J.P., Eisenhardt, K.M., Bingham, C.B., 2007. Developing theory through simulation methods. Academy of Management Review, 32(2), 480 - 499

Delucchi, A.M., Jacobson, M.Z., 2011. Providing all global energy with wind water and solar power, Part II: reliability, system and transmission costs, and policies. Energy Policy 39, $1154-1169$

Geels, F.W., 2002, Technological transitions as evolutionary reconfiguration processes: a multi-level perspective and a case-study. Research Policy 31, 1257 - 1274.

Geels, F.W., 2004. From sectoral systems of innovation to socio technical systems: insights about dynamics and change from sociology and institutional theory. Research Policy 33, 897 - 920.

Geels, FW., 2005. The dynamics of transitions in socio-technical systems: A multi-level analysis of the transition pathway from horse-drawn carriages to automobiles (1860-1930). Technology Analysis \& Strategic Management 17, 445 - 476

Geels, F.W., 2006a. The hygienic transition from cess pools to sewer systems (1840 - 1930): the dynamics of regime transformation. Research Policy 35, 1069 - 1082.

Geels F.W., 2006b. Major system change through stepwise reconfiguration: a multilevel analysis of the transformation of American factory production (1850 - 1930). Technology in Society 28, $445-476$.

Geels, F.W., Schot, J., 2007. Typology of sociotechnical transition pathways. Research Policy 36, 399417.

Geels, F.W., 2007a. Transformations of large technical systems: A multi level analysis of the Dutch highway system (1950-2000). Science technology Human Values 32, 123 - 149

Geels, F.W., 2007b. Analysing the breakthrough of rock 'n' roll (1930-1970) multi regime interaction and reconfiguration in the multi level perspective. Technological Forecasting and Social Change 74, 1411-1431 
Geels, F.W., 2010. Ontologies, socio-technical transitions (to sustainability), and the multi level perspective, Research Policy 39, 495 - 510

Haxeltine, A., Whitmarsh, L., Bergman, N., Rotmans, J., Schilperoord, M., Kohler, J., 2008. A conceptual framework for transition modelling. International Journal of Innovation and Sustainable Development 3(1-2), $93-114$

Holz, G, 2011. Modelling transitions: An appraisal of experiences and suggestions for research, environmental Innovation and Societal Transitions 1, 167 - 186

Jacobson, M.Z., Delucchi, A.M., 2011. Providing all global energy with wind water and solar power, Part I: Technologies, energy resources, quantities and areas of infrastructure, and materials. Energy Policy 39, $1154-1169$

Kohler, J., Whitmarsh, L., Nykvist, B., Schilperoord, M., Bergman, N., Haxeltine, A., 2009. A transitions model for sustainable mobility. Ecological Economics 68, p2985-2995

Maturana, H.R., Varela, F.J., 1980. Autopoiesis and cognition: The realization of the living. Dordrecht: D. Reidel Publishing

Raven, R., 2007. Co-evolution of waste and electricity regimes: Multi-regime dynamics in the Netherlands (1969-2003). Energy Policy 35, 2197 - 2208

Rip, A., Kemp, R., 1998. Technological change. In: Rayner, S., Malone, E.L. (Eds.), Human Choice and Climate Change. Battelle Press, Columbus, OH, pp. 327-399.

Safarzynska, K., Frenken, K., van den Bergh J. 2011. Evolutionary theorizing and modelling of sustainability transitions. Forthcoming in Research Policy.

Safarzynska, K., van den Bergh, J., 2010. Demand-supply coevolution with multiple increasing returns: policy analysis for unlocking and systems transitions. Technological Forecasting \& Social Change 77, 297-317.

Schot, J., Geels, F.W., 2007, Niches in evolutionary theories of technical change, Journal of Evolutionary Economics, 17, 605 - 622

Smith, A., Stirling, A., Berkhout, F., 2005. The governance of sustainable socio technical transitions. Research Policy 34, $1491-1510$

Sterman, J.D., Wittenberg, J., 1999, Path dependence, competition and succession in the dynamics of scientific revolution, Organization Science 10(3), $322-341$

Sterman, J.D., 1985. The growth of knowledge: Testing a theory of scientific revolutions with a formal model. Technology Forecasting and Social Change 28, $93-122$.

Timmermans, J. Haan, H., 2008. Special issue on computational and mathematical approaches to societal transitions. Computational and Mathematical Organization Theory 14(4), 263-265

Tushman, L.M., Anderson, P., 1986. Technological discontinuities and organizational environments. Administrative Science Quarterly 31(3), 439 - 465

Van de Poel, I., 2000. On the role of outsiders in technical development. Technology Analysis \& Strategic Management, 12(3), 383 - 397 
Van den Vleuten, E., Raven, R., 2006. Lock in and change: Distributed generation in Denmark in a long term perspective. Energy Policy 34, 3739 - 3748.

Verbong, G., Geels, F.W., 2007. The ongoing energy transition: lessons form a socio-technical, multi level analysis of the Dutch electricity system (1960-2004). Energy Policy 25, 1025 - 1037.

Wittenberg, J., 1992. On the very idea of a system dynamics model of Kuhnian science, System Dynamics Review 8(1), 21 - 33

Yucel, G., Mesa, C.M.C., 2008. Studying transition dynamics via focusing on underlying feedback integrations: modelling the Dutch waste management transition. Computational and Mathematical Organization Theory, 14, $320-349$

Yucel, G., van Daalen, C., 2008. Exploring transition dynamics: a case-based modeling study. In: Paper Presented at the Fifth Conference of the European Social Simulation Association ESSA 2008, Brescia, Italy

Appendix: Model Equations

\begin{tabular}{|c|c|c|}
\hline & Variable Name & Definition \\
\hline 1 & Required Niche Capacity & 'Total Niche Users'*'User Capacity Conversion Factor' \\
\hline 2 & Users outside niches & $(1000-' T o t a l$ Niche Users')/1000 \\
\hline 3 & Stability of Rules & 'Rule system stability' \\
\hline 4 & $\begin{array}{l}\% \text { of users using old regime } \\
\text { rules }\end{array}$ & ('Old Regime Unaware Users')/1000 \\
\hline 5 & $\begin{array}{l}\text { Max number of users } \\
\text { following new or old rules }\end{array}$ & $\begin{array}{l}\text { MAX('\% of users using old regime rules','\% of users using } \\
\text { new regime rules') }\end{array}$ \\
\hline 6 & Total New Capacity & 'New Regime Capacity'+NUMBER('Total Niche Capacity') \\
\hline 7 & Total Niche Capacity & ARRSUM(NUMBER('Niche Production Capacity')) \\
\hline 8 & $\begin{array}{l}\text { Tech Performance Transfer } \\
\text { to Regime }\end{array}$ & ARRSUM('Tech performance to Regime') \\
\hline 9 & Tech Performance increase & ARRSUM('Tech Perf Improvement') \\
\hline 10 & $\begin{array}{l}\text { Total Niche Users Entering } \\
\text { New Regime }\end{array}$ & ARRSUM('Users Entering New Regime') \\
\hline 11 & Actual Niche Users & ARRSUM('Niche Users') \\
\hline 12 & $\begin{array}{l}\text { Resource Transfer from } \\
\text { Incumbent Regime }\end{array}$ & 'Shift of Resources Flow' \\
\hline 13 & Resources Depreciation & $\begin{array}{l}\left(1-\mathrm{MIN}\left(1,{ }^{\prime} \text { Required old resources'))* MAX('Regime }\right.\right. \\
\text { Resource Usage Flow','Production regime } \\
\text { resources'/1<<yr >>) }\end{array}$ \\
\hline 14 & $\begin{array}{l}\text { Regime Outside Resources } \\
\text { Ratio }\end{array}$ & $\begin{array}{l}\text { 'Regime Total Resources Ratio'/'Outside Total Resources } \\
\text { Ratio'/10 }\end{array}$ \\
\hline 15 & Scope for Regulation Switch & $\begin{array}{l}\text { DELAYINF(MIN(1,'Scope for regulation'),1<<yr >>,1,'Scope } \\
\text { for regulation') }\end{array}$ \\
\hline 16 & Change scope for regulation & $\begin{array}{l}\text { ('Political pressure'/MAX }(1,(\text { 'New regime } \\
\text { competitiveness'/MAX }(1, \text { 'Old regime competitiveness')))- } \\
\text { 'Scope for regulation')/1<<yr>> }\end{array}$ \\
\hline 17 & Total System Capacity & $\begin{array}{l}\text { 'Total Regime Capacity'+NUMBER(ARRSUM('Niche } \\
\text { Production Capacity')) }\end{array}$ \\
\hline 18 & Total Niche Users & $\begin{array}{l}\text { 'Potential New niche Users'+ARRSUM('Niche } \\
\text { Users')+'Recurrent Niche Users' }\end{array}$ \\
\hline 19 & Users Entering New Regime & $($ 'Niche Users')*(1-'Niche Market Release') /1<<yr>> \\
\hline 20 & Niche R \& D Depreciation & 'Niche R \& D'*(1-'Niche Market Release')/1<<yr>>//'Tech \\
\hline
\end{tabular}




\begin{tabular}{|c|c|c|}
\hline & & performance to Regime' \\
\hline 21 & Total New Regime Users & 'New Regime Users'+'Dominant Niche Users' \\
\hline 22 & $\begin{array}{l}\text { Old Regime Production } \\
\text { Investment Flow }\end{array}$ & 'Capital Control'[INDEX(2)] \\
\hline 23 & Capital Control & $\begin{array}{l}\text { PRIORITYALLOC('Old Regime Production } \\
\text { Capital'/1<<yr }>>,\{\text { MAX(0/1<<yr }>>, \text { 'Investment shift'),'Old } \\
\text { regime production investment' }\},\{1,1\})\end{array}$ \\
\hline 24 & Investment Flow & $\begin{array}{l}\text { Capital Control'[INDEX(1)]*MIN(1,'Required New Regime } \\
\text { Production Investment') }\end{array}$ \\
\hline 25 & $\begin{array}{l}\text { Niche PP ratio market } \\
\text { threshold }\end{array}$ & 'Niche market threshold'*'Niche dominant tech PP ratio' \\
\hline 26 & Niche dominant tech PP ratio & $\begin{array}{l}\text { MIN(1,RUNMAX(ARRMAX('Protected Niche Perf Price } \\
\text { Ratio'))/'Incumbent Perf Price Ratio') }\end{array}$ \\
\hline 27 & Niche market threshold & $\begin{array}{l}\text { MIN(1,RUNMAX('Dominant Niche Users')/(('Total old regime } \\
\text { users'+ARRSUM('Niche Users'))*0.05)) }\end{array}$ \\
\hline 28 & $\begin{array}{l}\text { Knowledge Transfer to } \\
\text { Regime }\end{array}$ & $\begin{array}{l}\text { 'Niche Cumulative Knowledge'*(1-ROUND('Niche Market } \\
\text { Release'))/1<<yr>>*'Switch of knowledge Transfer to } \\
\text { regime' }\end{array}$ \\
\hline 29 & $\begin{array}{l}\text { Niche knowledge } \\
\text { accumulation }\end{array}$ & $\begin{array}{l}\text { (ARRSUM('Niche Rate of Knowledge } \\
\text { Accumulation'))/1<<yr>>} \text { ROUND('Niche Market Release') }\end{array}$ \\
\hline 30 & $\begin{array}{l}\text { Niche Rate of Knowledge } \\
\text { Accumulation }\end{array}$ & 'Technology Performance'/MAX(1,'Niche Tech Learning') \\
\hline 31 & Tech performance to Regime & $\begin{array}{l}\text { 'Technology Performance'/1<<yr }>>^{*}(1-\text { 'Niche Market } \\
\text { Release' })^{*} \text { Switch of tech performance transfer to regime' }\end{array}$ \\
\hline 32 & Tech Learning Rate & 'Product Discard'*'Tech R \& D'*1<<yr>> \\
\hline 33 & $\begin{array}{l}\text { Recurrent Users Entering } \\
\text { New Regime }\end{array}$ & $\begin{array}{l}\text { ('Recurrent Niche Users')*(1-'Niche Market Release')/'Niche } \\
\text { Product Use Time' }\end{array}$ \\
\hline 34 & $\begin{array}{l}\text { Redistribution of Users With } \\
\text { Preference }\end{array}$ & $\begin{array}{l}\text { PRIORITYALLOC('Recurrent Niche Users', } \\
\text { ('Recurrent Niche Users'*'User Choice'.'Competitiveness } \\
\text { diff'), \{'User Choice'.'Competitiveness diff'[INDEX(1)],'User } \\
\text { Choice'.'Competitiveness diff'[INDEX(2)],'User } \\
\text { Choice'.'Competitiveness diff'[INDEX(3)]\}) }\end{array}$ \\
\hline 35 & $\begin{array}{l}\text { Potential Users Entering New } \\
\text { Regime }\end{array}$ & $\begin{array}{l}\text { ('Potential New niche Users') } \\
{ }^{*}(1-' N i c h e \text { Market Release')/1<<yr>> }\end{array}$ \\
\hline 36 & $\begin{array}{l}\text { Regime effect induced Tech } \\
\text { Perf Targets }\end{array}$ & 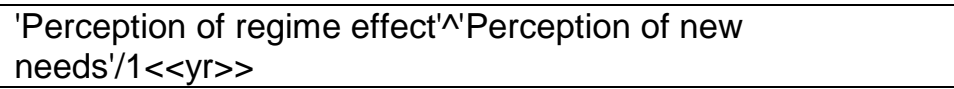 \\
\hline 37 & Niche Critical Mass Indicator & $\begin{array}{l}\text { MIN(1,MAX(IF ('Dominant Niche Users'/'Total old regime } \\
\text { users'<'Market niche development threshold',0,1) } \\
\text {,'New Regime Users')) }\end{array}$ \\
\hline 38 & Scaled Niche Tech Capacity & 'Niche Production Capacity'/100 \\
\hline 39 & Required Capacity & $\begin{array}{l}\text { MAX }(0, ' \text { 'Niche Required Capacity'-'Niche Production } \\
\text { Capacity'*1<<yr }>>)\end{array}$ \\
\hline 40 & New Users from Niche & 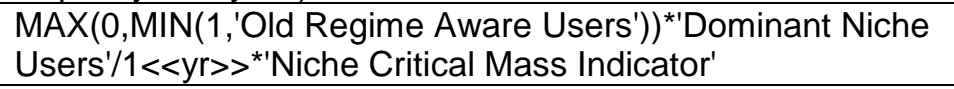 \\
\hline 41 & Niche Market Release & $\begin{array}{l}\text { MAX(0,ARRMIN('Niche Protection Review')/MAX(1,'New } \\
\text { Regime Development Indicator')) }\end{array}$ \\
\hline 42 & Dominant Niche Users & ARRSUM('Niche Users')+'Recurrent Niche Users' \\
\hline 43 & $\begin{array}{l}\text { Protected Niche Perf Price } \\
\text { Ratio }\end{array}$ & 'Regulation - Incentives'*('Perf Price Ratio') \\
\hline 44 & Niche Potential Users & $\begin{array}{l}\text { MAX }\left(0, M I N\left(1,,^{\prime} \text { Old Regime Aware users'/MAX(1,('Regulation }\right.\right. \\
\text { - Incentives'-1)*RUNMAX(ARRMAX('Perceived Tech } \\
\text { Improvement') )*'Window of Opportunity' * 'Niche Market } \\
\text { Release' })))^{*}\left({ }^{*} \text { Regulation - Incentives'-1)* RUNMAX( }\right. \\
\text { ARRMAX('Perceived Tech Improvement')) } \\
{ }^{*} \text { Window of Opportunity' * 'Niche Market Release'/1<<yr }>>\end{array}$ \\
\hline 45 & Incumbent Perf Price Ratio & 'Old tech efficiency'/'Incumbent Tech Price' \\
\hline 46 & Returning Users & $\begin{array}{l}\text { Redistribution of Users With Preference'*'Niche Market } \\
\text { Release'/1<<yr>> }\end{array}$ \\
\hline 47 & Performance Price Ratio & $\begin{array}{l}\text { (('Technology Performance'/MAX(1,ARRMAX('Technology } \\
\text { Performance')))/'Tech Price') }\end{array}$ \\
\hline
\end{tabular}




\begin{tabular}{|c|c|c|}
\hline 48 & Tech Price Change & ('Unit cost T1'-'Tech Price')/'Price adjustment time' \\
\hline 49 & Unit cost & $\begin{array}{l}\text { Initial Tech Cost'*MIN('Cumulative Production'^'Tech Cost } \\
\text { Exponent',1) }\end{array}$ \\
\hline 50 & OEM Production & Production \\
\hline 51 & Niches Expenditure Stream & 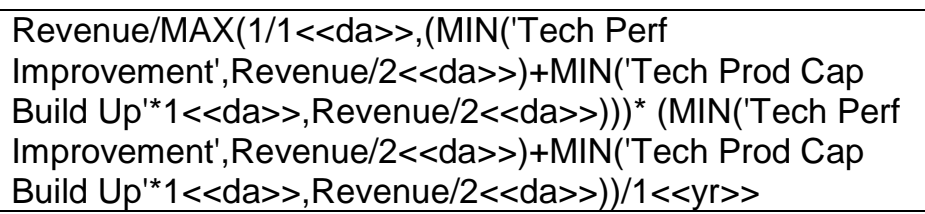 \\
\hline 52 & Niches Revenue Stream & (Sales+'FC Allocation'/1<<yr >>) \\
\hline 53 & Product Discard & MAX(0,'Niche Users')/'Niche Product Use Time' \\
\hline 54 & New Niche Users & 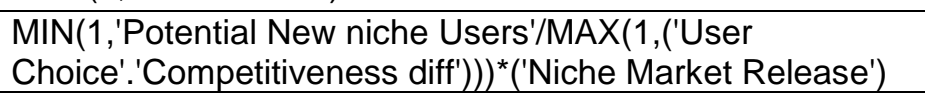 \\
\hline 55 & Capacity Depreciation & 'Niche Production Capacity'/'Capacity depreciation time' \\
\hline 56 & $\begin{array}{l}\text { Revenue Coverage for Niche } \\
\text { Required Capacity }\end{array}$ & MAX(0,MIN(1,Revenue/MAX(1,'Required Capacity'))) \\
\hline 57 & $\begin{array}{l}\text { Niche Production Capacity } \\
\text { build up }\end{array}$ & $\begin{array}{l}\text { FOR (i=TechRange|MAX(0,'Revenue Coverage for Niche } \\
\text { Required Capacity'[INDEX(i)] *DELAYMTR('Required } \\
\text { Capacity'[INDEX(i)],'Cap build up } \\
\text { delay'[INDEX(i)], } 1,0))) / 1<<\text { yr }^{\wedge} 2>>\end{array}$ \\
\hline 58 & Sales & $\operatorname{MAX}(0, \operatorname{MIN}($ Inventory,'Niche Users') $) / 1<<y r>>$ \\
\hline 59 & Niche Production & $\begin{array}{l}\text { FOR (i=TechRange|MAX(0/1<<yr }>>, \text { MIN('Niche Production } \\
\text { Capacity'[INDEX(i)],DELAYMTR('Niche } \\
\text { Users'[INDEX(i)], } 1<<<\text { yr }>>, 1,0) / 1<<y r>>)))\end{array}$ \\
\hline 60 & $\begin{array}{l}\text { Technology Expectations } \\
\text { Fullfilment }\end{array}$ & $\begin{array}{l}\text { Tech Expectations'/MAX(1,'Desired Technology } \\
\text { Performance') }\end{array}$ \\
\hline 61 & Periodic Target Adjustment & $\begin{array}{l}\text { NUMBER(PULSE(1,STARTTIME+0<<yr>>,'Target } \\
\text { Adjustment Time')) }\end{array}$ \\
\hline 62 & Input Tech Expectations & $\begin{array}{l}\text { \{PULSE(1,STARTTIME,500<<yr }>>), \\
\text { PULSE(1,STARTTIME+'Tech } 1 \text { headstart', } 500<<y r>>)\}\end{array}$ \\
\hline 63 & FC accumulation & Flow of Financial Capital'/1<<yr $>>$ \\
\hline 64 & $\begin{array}{l}\text { Net Change In Desired Tech } \\
\text { Perf }\end{array}$ & $\begin{array}{l}\text { ('Technology Performance'-'Desired Technology } \\
\text { Performance')/'Goal Adjustment Time'*'Periodic Target } \\
\text { Adjustment' }\end{array}$ \\
\hline 65 & FC expenditure & ARRSUM('Tech R \& D') \\
\hline 66 & Error in Tech Perception & 'Technology Performance'-'Perceived Tech Improvement' \\
\hline 67 & $\begin{array}{l}\text { Perceived Tech Improvement } \\
\text { Change }\end{array}$ & 'Error in Tech Perception'/'Perception Adjustment Time' \\
\hline 68 & Tech Expect Change & ('Perceived Tech Improvement'-'Tech Expectations') \\
\hline 69 & Tech Perf Improvement & $\begin{array}{l}\text { ('Niche R \& D'-'Technology Performance')/'Tech Perf } \\
\text { Improvement Time'/MAX(1,'Technology Performance') } \\
\text { *'New Regime Scientists Ratio' *ROUND('Niche Market } \\
\text { Release') }\end{array}$ \\
\hline 70 & Tech R \& D & 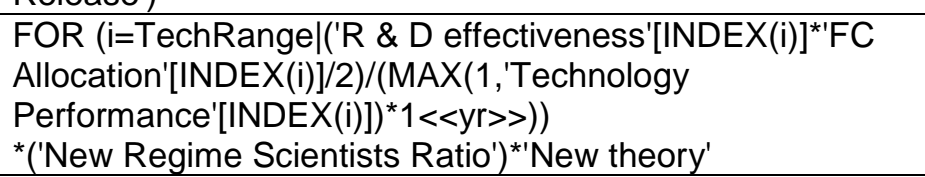 \\
\hline 71 & FC Allocation & $\begin{array}{l}\text { PRIORITYALLOC(MAX(0,('Financial } \\
\text { Capital')),MAX(0,'Desired Technology } \\
\text { Performance'),MAX(0,'Technology Expectations } \\
\text { Fullfilment')*'Perf Price Ratio')*'Niche Market Release' }\end{array}$ \\
\hline 72 & Resource Locus & 'Scaled RRes ratio' \\
\hline 73 & $\begin{array}{l}\text { Coordination of Adaptive } \\
\text { Response }\end{array}$ & 'Scaled alignment rules \& activities' \\
\hline 74 & Normalised Policy WoO & 1-'Window of Opportunity' \\
\hline 75 & Niche & CEIL(MAX(0,1-'Niche Market Release')) \\
\hline 76 & Purposive_Transition & MAX(0,MIN(1,'4th quadrant')) \\
\hline 77 & Emergent_Transformation & $\operatorname{MIN}(1$, '3rd quadrant') \\
\hline
\end{tabular}




\begin{tabular}{|c|c|c|}
\hline 78 & Reorientation_of_Trajectories & MIN $(1, ' 2 d$ quadrant') \\
\hline 79 & Endogenous_Renewal & MIN(1,'1st quadrant') \\
\hline 80 & Quadrant 4 & $\begin{array}{l}\text { FOR (Quadrants='Endogenous Renewal'..'Purposive } \\
\text { Transition'|'Transition } \\
\text { Quadrants'[INDEX(NUMERICAL(Quadrants))]) *'Array 4' }\end{array}$ \\
\hline 81 & Quadrant 3 & $\begin{array}{l}\text { FOR (Quadrants='Endogenous Renewal'..'Purposive } \\
\text { Transition'|'Transition } \\
\text { Quadrants'[INDEX(NUMERICAL(Quadrants))]) *'Array 3' }\end{array}$ \\
\hline 82 & Quadrant 2 & $\begin{array}{l}\text { FOR (Quadrants='Endogenous Renewal'..'Purposive } \\
\text { Transition'|'Transition } \\
\text { Quadrants'[INDEX(NUMERICAL(Quadrants))]) *'Array 2' }\end{array}$ \\
\hline 83 & Quadrant 1 & $\begin{array}{l}\text { FOR (Quadrants='Endogenous Renewal'..'Purposive } \\
\text { Transition'|'Transition } \\
\text { Quadrants'[INDEX(NUMERICAL(Quadrants))]) *'Array 1' }\end{array}$ \\
\hline 84 & Transition Quadrants & \{'1st quadrant','2d quadrant','3rd quadrant','4th quadrant'\} \\
\hline 85 & $\begin{array}{l}\text { Production Capacity } \\
\text { Alignment }\end{array}$ & $\begin{array}{l}\text { (MAX('Old Regime Capacity','New Regime } \\
\text { Capacity')/SUM('New Regime Capacity','Old Regime } \\
\text { Capacity')) }\end{array}$ \\
\hline 86 & Old Aware Total Users Ratio & 'Old Regime Aware Users'/'Total members' \\
\hline 87 & Membershift Shift Actual & $\begin{array}{l}\text { 'Old Regime Members Control'[INDEX(2)] *'Switch } \\
\text { Membership Shift' }\end{array}$ \\
\hline 88 & $\begin{array}{l}\text { Old Regime Members } \\
\text { Disappear }\end{array}$ & 'Old Regime Members Control'[INDEX(1)] \\
\hline 89 & $\begin{array}{l}\text { Old Regime Members } \\
\text { Control }\end{array}$ & $\begin{array}{l}\text { PRIORITYALLOC('Old regime members'/1<<yr }>>,\{\text { 'Creative } \\
\text { destruction','Membership shift' }\},\{0,0\})\end{array}$ \\
\hline 90 & $\begin{array}{l}\text { New Total Production } \\
\text { Resources Ratio }\end{array}$ & $\begin{array}{l}\text { 'Production resources of the new regime'/('Production } \\
\text { regime resources'+'Production resources of the new } \\
\text { regime') }\end{array}$ \\
\hline 91 & Niche Perf Price Ratio & RUNMAX(ARRMAX('Perf Price Ratio')) \\
\hline 92 & $\begin{array}{l}\text { New Regime Technology } \\
\text { Expectations Fullfilment }\end{array}$ & $\begin{array}{l}\text { 'New tech efficiency'/MAX(1,'New Regime Technology } \\
\text { Expectations') }\end{array}$ \\
\hline 93 & $\begin{array}{l}\text { New Production Capital from } \\
\text { Regulation Incentives }\end{array}$ & $\begin{array}{l}\text { ('Regulation - Incentives'-1) } \text { ('Regulation Incentives coverage }^{*} \text { of New Production Capital Needs' *'Required New Regime } \\
\text { Production Investment'/1<<yr >> }\end{array}$ \\
\hline 94 & 4th quadrant & 'Purposive Transition' \\
\hline 95 & 3rd quadrant & 'Emergent Transformation' \\
\hline 96 & 2d quadrant & 'Reorientation of Trajectories' \\
\hline 97 & 1st quadrant & 'Endogenous Renewal' \\
\hline 98 & $\begin{array}{l}\text { Regulation Incentives } \\
\text { coverage of New Production } \\
\text { Capital Needs }\end{array}$ & $\begin{array}{l}\text { MIN(1,'Regulation - Incentives'-1/MAX(1,'Required New } \\
\text { Regime Production Investment'))*MIN(1,'New regime } \\
\text { members') }\end{array}$ \\
\hline 99 & $\begin{array}{l}\text { Required New Regime } \\
\text { Production Investment }\end{array}$ & $\begin{array}{l}\text { MIN }(1, \text { 'Regulation - Incentives'-1/MAX(1,'Required New } \\
\text { Regime Production Investment'))*MIN(1,'New regime } \\
\text { members') }\end{array}$ \\
\hline 100 & Actual User Transition & $\begin{array}{l}\text { MAX }(0<<y r>>, M I N(1<<y r>>, ' \text { 'Old Regime Aware } \\
\text { Users'/MAX }(1 / 1<<y r>>, ' \text { 'User Transition' })))^{*} \text { User } \\
\text { Transition'/1<<yr }>>\end{array}$ \\
\hline 101 & Lowering of Barriers & 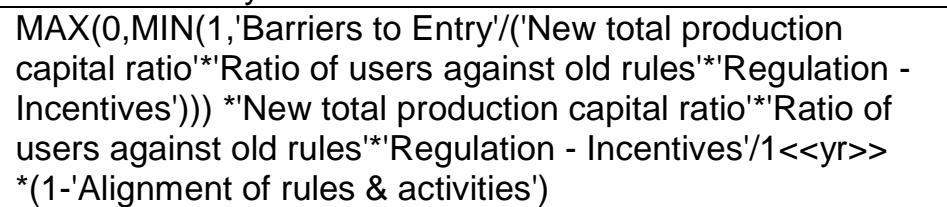 \\
\hline 102 & Raising Barriers & $\begin{array}{l}\text { MAX(0,(MAX('Regime Total Members Ratio','Outside total } \\
\text { members ratio')-'Barriers to Entry'))/1<<yr>> }\end{array}$ \\
\hline 103 & $\begin{array}{l}\text { Tech Performance Transfer } \\
\text { from Niche }\end{array}$ & $\begin{array}{l}\text { Tech performance to Regime'* \% of Niche Tech Perf to } \\
\text { Regime' }^{\prime}\end{array}$ \\
\hline 104 & $\begin{array}{l}\text { New Regime Development } \\
\text { Indicator }\end{array}$ & $\begin{array}{l}\text { MAX(0,'Competitiveness diff'.'Competitiveness diff'"'New Old } \\
\text { users ratio'*'Outside total members ratio') }\end{array}$ \\
\hline 105 & Shift of Resources Flow & 'Resource Allocation'[INDEX(1)] \\
\hline
\end{tabular}




\begin{tabular}{|c|c|c|}
\hline 106 & $\begin{array}{l}\text { Regime Resource Usage } \\
\text { Flow }\end{array}$ & 'Resource Allocation'[INDEX(2)] \\
\hline 107 & Resource Allocation & $\begin{array}{l}\text { PRIORITYALLOC('Production regime } \\
\text { resources'/1<<yr }>>,\{\text { 'Shift of resources','Regime Resource } \\
\text { Usage'\},\{1,1\}) }\end{array}$ \\
\hline 108 & New Old Regime Scientists & 'New Regime Scientists'/MAX('Current Regime Scientists',1) \\
\hline 109 & Creative destruction & 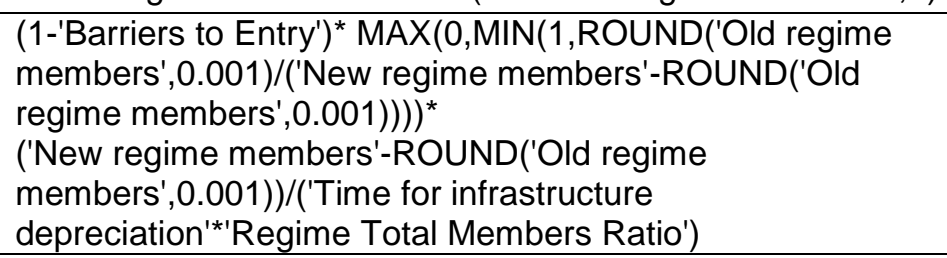 \\
\hline 110 & Total Aware Users & 'Total New Regime Users'+'Old Regime Aware Users' \\
\hline 111 & Niche Protection Review & $\begin{array}{l}\text { MAX }(0, M I N(1, ' I n c u m b e n t \text { Perf Price Ratio'/'Protected Niche } \\
\text { Perf Price Ratio')) }\end{array}$ \\
\hline 112 & New Price-Perf Ratio & $\begin{array}{l}\text { 'New Regime Users'*'New Regime Capacity'/'New tech } \\
\text { efficiency' }\end{array}$ \\
\hline 113 & Old Price-Perf Ratio & $\begin{array}{l}\text { ('Old Regime Unaware Users'+'Old Regime Aware } \\
\text { Users')*'Old Regime Capacity'/'Old tech efficiency' }\end{array}$ \\
\hline 114 & $\begin{array}{l}\text { Experimental anomalies } \\
\text { explained }\end{array}$ & $\begin{array}{l}\text { MIN('Number of experimental anomalies','New } \\
\text { theory'/MAX }(1, \text { 'Number of experimental anomalies')) } \\
/ 1<<y \text { r }>>\end{array}$ \\
\hline 115 & Experimental anomalies & $\begin{array}{l}\text { MAX(0/1<<yr }>>\text {,'Experimental Observation'* }(1-' C o n f i d e n c e \\
\text { in New Regime')) }\end{array}$ \\
\hline 116 & $\begin{array}{l}\text { New total production capital } \\
\text { ratio }\end{array}$ & $\begin{array}{l}\text { 'New Regime Production Capital'/('Old Regime Production } \\
\text { Capital'+'New Regime Production Capital') }\end{array}$ \\
\hline 117 & $\begin{array}{l}\text { User capacity needs } \\
\text { coverage }\end{array}$ & $\begin{array}{l}\text { 'Total Regime Capacity' /('Required New Regime } \\
\text { Capacity'+'Required old regime capacity') }\end{array}$ \\
\hline 118 & Knowledge generation & $\begin{array}{l}\text { ('New technical solutions'/MAX(1,'Flow of Financial } \\
\text { Capital'))/1<<yr>> }\end{array}$ \\
\hline 119 & $\begin{array}{l}\text { Ratio of old regime users } \\
\text { against rules }\end{array}$ & $\begin{array}{l}\text { Old Regime Aware Users'/('Old Regime Aware } \\
\text { Users'+ROUND('Old Regime Unaware Users')) }\end{array}$ \\
\hline 120 & $\begin{array}{l}\text { Formation of new actor } \\
\text { network }\end{array}$ & 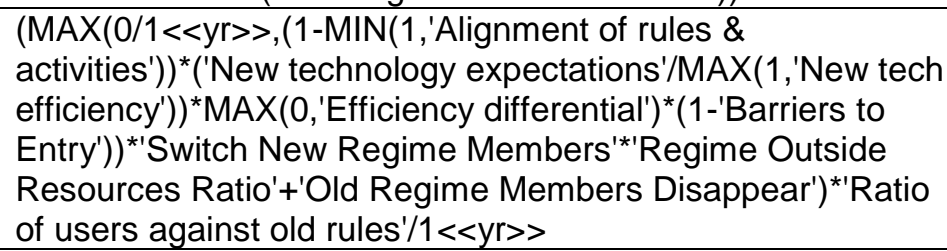 \\
\hline 121 & New regime evaluation & $\begin{array}{l}\text { 'Efficiency differential'*'New old users'*'New tech } \\
\text { efficiency'/MAX(1,'New Regime Technology Expectations') }\end{array}$ \\
\hline 122 & Resistance build up & $\begin{array}{l}\text { MAX((MAX('Regime Total Members Ratio','Outside total } \\
\text { members ratio')-'Incumbent resistance'),0)/1<<yr }>>\end{array}$ \\
\hline 123 & Total production investment & $\begin{array}{l}\text { 'New regime production investment'+'Old regime production } \\
\text { investment' }\end{array}$ \\
\hline 124 & $\begin{array}{l}\text { Production Resources } \\
\text { Alignment }\end{array}$ & $\begin{array}{l}\text { (MAX('Production regime resources','Production resources } \\
\text { of the new regime')/ SUM('Production regime } \\
\text { resources','Production resources of the new regime')) }\end{array}$ \\
\hline 125 & $\begin{array}{l}\text { Scaled alignment rules \& } \\
\text { activities }\end{array}$ & 'Alignment of rules \& activities'-0.5 \\
\hline 126 & $\begin{array}{l}\text { Pursposive Transition } \\
\text { Change }\end{array}$ & $\begin{array}{l}\text { IF ('Scaled alignment rules \& activities'>0 AND 'Scaled } \\
\text { RRes ratio'<0,1,0)/1<<yr>> }\end{array}$ \\
\hline 127 & $\begin{array}{l}\text { Emergent Transformation } \\
\text { Change }\end{array}$ & $\begin{array}{l}\text { IF ('Scaled alignment rules \& activities'<0 AND 'Scaled } \\
\text { RRes ratio' }<0,1,0) / 1<<y r>>\end{array}$ \\
\hline 128 & $\begin{array}{l}\text { Reorientation of Trajectories } \\
\text { Change }\end{array}$ & $\begin{array}{l}\text { IF ('Scaled alignment rules \& activities'<0 AND 'Scaled } \\
\text { RRes ratio' }>0,1,0) / 1<<y r>>\end{array}$ \\
\hline 129 & $\begin{array}{l}\text { Endogenous renewal } \\
\text { Change }\end{array}$ & $\begin{array}{l}\text { IF ('Scaled alignment rules \& activities'>0 AND 'Scaled } \\
\text { RRes ratio' }>0,1,0) / 1<<y r>>\end{array}$ \\
\hline 130 & Alignment of rules \& activities & 'Alignment of activities'*'Rule System Alignment' //1 \\
\hline 131 & Scaled rule system alignment & 'Rule System Alignment'-0.5 \\
\hline 132 & Scaled RRes ratio & 'Regime Total Resources Ratio'-0.5 \\
\hline 133 & Scaled alignment of activities & 'Alignment of activities'-0.5 \\
\hline
\end{tabular}




\begin{tabular}{|c|c|c|}
\hline 134 & New tech potential & 'New tech efficiency'*'New theory' \\
\hline 135 & $\begin{array}{l}\text { Effects of New Paradigm on } \\
\text { Expectations }\end{array}$ & $\begin{array}{l}\text { New technology expectations'*'New tech potential'*'New } \\
\text { Regime Scientists Ratio' }\end{array}$ \\
\hline 136 & New technology & $\begin{array}{l}\text { ('Effect of outsiders on expectations'*'Effects of new } \\
\text { paradigm on expectations' } \\
\text { /'Regulation - Incentives')/MAX(1,'New technology } \\
\text { expectations') }\end{array}$ \\
\hline 137 & $\begin{array}{l}\text { Effect of outsiders on } \\
\text { expectations }\end{array}$ & $\begin{array}{l}\text { ('Efficiency differential'*'Old Aware Total Users Ratio'+'Flow } \\
\text { of Financial Capital'*'New Total Production Resources } \\
\text { Ratio"'’'Outside total members ratio') }\end{array}$ \\
\hline 138 & $\begin{array}{l}\text { Change in new technology } \\
\text { expectations }\end{array}$ & $\begin{array}{l}\text { MAX('New technology','New tech efficiency')*'New } \\
\text { Technology Expectations Fullfilment'-'New technology } \\
\text { expectations')/('Time To adjust expectations') }\end{array}$ \\
\hline 139 & Production Capital Alignment & $\begin{array}{l}\text { (MAX('Old Regime Production Capital','New Regime } \\
\text { Production Capital')/SUM('Old Regime Production } \\
\text { Capital','New Regime Production Capital')) }\end{array}$ \\
\hline 140 & $\begin{array}{l}\text { Regime Membership } \\
\text { Alignment }\end{array}$ & $\begin{array}{l}\text { (MAX('Old regime members','New regime } \\
\text { members')/SUM('Old regime members','New regime } \\
\text { members')) }\end{array}$ \\
\hline 141 & Incumbent alignment & $\begin{array}{l}\text { (MAX('Incumbent resistance','Incumbent resistance } \\
\text { disposed')/SUM('Incumbent resistance','Incumbent } \\
\text { resistance disposed')) }\end{array}$ \\
\hline 142 & Science Alignment & $\begin{array}{l}\text { (MAX('Confidence in Current Regime','Confidence in New } \\
\text { Regime')/SUM('Confidence in Current Regime','Confidence } \\
\text { in New Regime')) }\end{array}$ \\
\hline 143 & Needs alignment & $\begin{array}{l}\text { (MAX('Perception of current needs','Perception of new } \\
\text { needs')/SUM('Perception of current needs','Perception of } \\
\text { new needs')) }\end{array}$ \\
\hline 144 & User alignment & $\begin{array}{l}\text { (MAX('Old Regime Unaware Users','Old Regime Aware } \\
\text { Users','Total New Regime Users') /SUM('Old Regime } \\
\text { Unaware Users','Old Regime Aware Users','Total New } \\
\text { Regime Users')) }\end{array}$ \\
\hline 145 & Alignment of activities & $\begin{array}{l}\text { AVERAGE('Production Capacity Alignment','Regime } \\
\text { Membership Alignment', 'Normalised Policy WoO', } \\
\text { 'Production Capital Alignment', 'Rule System } \\
\text { Alignment','Science Alignment', 'Incumbent alignment', } \\
\text { 'Production Resources Alignment') } \\
\text { *'Switch Alignment of Activities' } \\
\text { +(1-'Switch Alignment of Activities') }\end{array}$ \\
\hline 146 & Old new capacity ratio & $\begin{array}{l}\text { 'Old Regime Capacity'/('New Regime Capacity'+'Old Regime } \\
\text { Capacity') }\end{array}$ \\
\hline 147 & Total resources inflow & $\begin{array}{l}\text { ('Resources supply'+'Shift of resources'+'Shift of resources') } \\
\text { /MAX }(1 / 1<<y r>>\text {,'Resource Usage') }\end{array}$ \\
\hline 148 & Total capital inflow & 'Investment shift'+'New regime production capital inflow' \\
\hline 149 & Total capital & $\begin{array}{l}\text { 'New Regime Production Capital'+'Old Regime Production } \\
\text { Capital'+'Flow of Financial Capital' }\end{array}$ \\
\hline 150 & $\begin{array}{l}\text { Regulation - Incentives effect } \\
\text { on new tech efficiency }\end{array}$ & 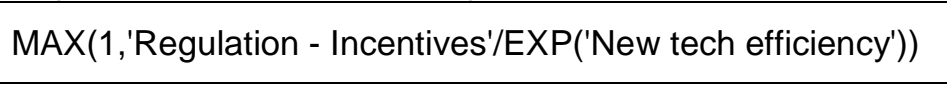 \\
\hline 151 & Total resource & $\begin{array}{l}\text { 'Production regime resources'+'Production resources of the } \\
\text { new regime' }\end{array}$ \\
\hline 152 & New Regime Scientists Ratio & 'New Regime Scientists'/'Total scientists' \\
\hline 153 & $\begin{array}{l}\text { Current Regime Scientists } \\
\text { Ratio }\end{array}$ & 'Current Regime Scientists'/'Total scientists' \\
\hline 154 & Required old resources & Required old regime capacity' \\
\hline 155 & $\begin{array}{l}\text { Old regime resource } \\
\text { shortage }\end{array}$ & $\begin{array}{l}\text { MAX }(0, ' \text { Required old resources'-'Production regime } \\
\text { resources') }\end{array}$ \\
\hline 156 & New regime effect & $\begin{array}{l}\text { ('Total New Regime Users')/MAX }(1, \text { 'New tech } \\
\text { efficiency')*'New Old users ratio'/1<<yr }>>\end{array}$ \\
\hline 157 & Total old regime users & 'Old Regime Aware Users'+'Old Regime Unaware Users' \\
\hline 158 & $\begin{array}{l}\text { New regime resource } \\
\text { shortage }\end{array}$ & 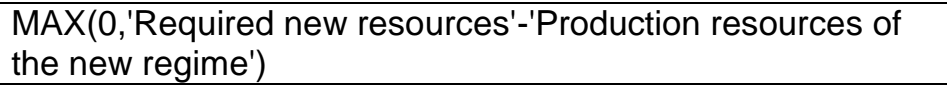 \\
\hline
\end{tabular}




\begin{tabular}{|c|c|c|}
\hline 159 & Required new resources & Required New Regime Capacity' \\
\hline 160 & Awareness Shift & $\begin{array}{l}\text { Perception of regime effect'*'Confidence in New } \\
\text { Regime'/1<<yr >> *ROUND('Old Regime Unaware } \\
\text { Users',0.001)/('Old Regime Unaware Users'+'Old Regime } \\
\text { Aware Users') }\end{array}$ \\
\hline 161 & Old regime sufficiency & $\begin{array}{l}\text { 'Old Regime Capacity'/MAX(1,'Old Regime Aware } \\
\text { Users') } 10\end{array}$ \\
\hline 162 & $\begin{array}{l}\text { Required new regime } \\
\text { capacity investment }\end{array}$ & $\begin{array}{l}\text { ROUND('Required New Regime Capacity'-'New Regime } \\
\text { Capacity',0.1) }\end{array}$ \\
\hline 163 & Old capital capacity ratio & 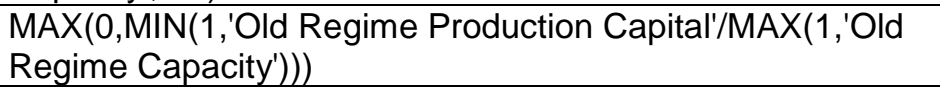 \\
\hline 164 & $\begin{array}{l}\% \text { resources outside the } \\
\text { regime }\end{array}$ & $\begin{array}{l}\text { 'Production resources of the new regime'/('Production } \\
\text { regime resources'+'Production resources of the new } \\
\text { regime') }\end{array}$ \\
\hline 165 & Required old regime capacity & $\begin{array}{l}\text { ('Old Regime Unaware Users'+'Old Regime Aware Users') } \\
\text { *'User Capacity Conversion Factor' }\end{array}$ \\
\hline 166 & $\begin{array}{l}\text { Outside Total Resources } \\
\text { Ratio }\end{array}$ & $\begin{array}{l}\text { 'Production resources of the new regime'/('Production } \\
\text { regime resources'+'Production resources of the new } \\
\text { regime') }\end{array}$ \\
\hline 167 & $\begin{array}{l}\text { Regime Total Resources } \\
\text { Ratio }\end{array}$ & $\begin{array}{l}\text { ('Production regime resources'+'Resources Transferred from } \\
\text { Incumbent Regime')//('Production regime } \\
\text { resources'+'Production resources of the new regime') }\end{array}$ \\
\hline 168 & $\begin{array}{l}\text { New Capital Sufficiency for } \\
\text { Capacity investment }\end{array}$ & $\begin{array}{l}\text { MIN(1,('New Regime Production Capital'+'Regulation - } \\
\text { Incentives')/MAX(1,'Required new regime capacity } \\
\text { investment')) }\end{array}$ \\
\hline 169 & $\begin{array}{l}\text { New Regime Capacity } \\
\text { Shortage }\end{array}$ & $\begin{array}{l}\text { MIN('New Regime Capacity'/MAX(1,'Required New Regime } \\
\text { Capacity'),1) }\end{array}$ \\
\hline 170 & $\begin{array}{l}\text { Required New Regime } \\
\text { Capacity }\end{array}$ & $\begin{array}{l}\text { ROUND('New Regime Users',0.1)*'User Capacity } \\
\text { Conversion Factor' }\end{array}$ \\
\hline 171 & $\begin{array}{l}\text { New regime production } \\
\text { investment }\end{array}$ & $\begin{array}{l}\text { MAX('New capacity increase'*MAX(MIN(1,'New Regime } \\
\text { Production Capital'),0),(1-MIN(1,ROUND(NUMBER('New } \\
\text { capacity increase'),0.1)))*'New Regime Production } \\
\text { Capital'/'Time for infrastructure depreciation') }\end{array}$ \\
\hline 172 & $\begin{array}{l}\text { New regime production } \\
\text { capital inflow }\end{array}$ & $\begin{array}{l}\text { New Production Capital from Regulation Incentives'+'New } \\
\text { regime production investment'*MIN }(1, \text { 'New regime } \\
\text { members') }\end{array}$ \\
\hline 173 & $\begin{array}{l}\text { Old regime production } \\
\text { investment }\end{array}$ & $\begin{array}{l}\text { MAX('Old Regime Capacity'/'Time for infrastructure } \\
\text { depreciation'*MAX(MIN(1,'Old Regime Production } \\
\text { Capital'),0),'Old Regime Production Capital'/'Time for } \\
\text { infrastructure depreciation') }\end{array}$ \\
\hline 174 & $\begin{array}{l}\text { Old regime production capital } \\
\text { inflow }\end{array}$ & $\begin{array}{l}\text { ROUND(MIN('Old regime production } \\
\text { investment',MAX('Regime Total Members Ratio'*('Old } \\
\text { Regime Aware Users'+'Old regime } \\
\text { members'),0)/1<<yr>>),0.001/1<<yr>>) }\end{array}$ \\
\hline 175 & Total investment & $\begin{array}{l}\text { 'New Regime Production Capital'+'Old Regime Production } \\
\text { Capital' }\end{array}$ \\
\hline 176 & Total Regime Capacity & 'New Regime Capacity'+'Old Regime Capacity' \\
\hline 177 & $\begin{array}{l}\text { Compound efficiency } \\
\text { differential }\end{array}$ & 'Resource diff'^'Efficiency differential' \\
\hline 178 & $\begin{array}{l}\text { Ratio of users against old } \\
\text { rules }\end{array}$ & $\begin{array}{l}\text { ROUND(('Old Regime Aware Users'+'New Regime } \\
\text { Users'+'Total Niche Users')/('Old Regime Unaware } \\
\text { Users'+'Old Regime Aware Users'+'Total New Regime } \\
\text { Users'+'Total Niche Users'),0.0001) }\end{array}$ \\
\hline 179 & Resource differential & $\begin{array}{l}\text { ABS('Production resources of the new regime'/('Production } \\
\text { resources of the new regime'+'Production regime } \\
\text { resources')) }\end{array}$ \\
\hline 180 & Regime Total Members Ratio & $\begin{array}{l}\text { 'Old regime members'/('Old regime members'+'New regime } \\
\text { members') }\end{array}$ \\
\hline 181 & Outside total members ratio & $\begin{array}{l}\text { MIN(1,'New regime members'/('Old regime members'+'New } \\
\text { regime members')) }\end{array}$ \\
\hline 182 & Old New users ratio & $\begin{array}{l}\text { MAX(0,'Old Regime Aware Users'+'Old Regime Unaware } \\
\text { Users')/('Total New Regime Users'+'Old Regime Aware }\end{array}$ \\
\hline
\end{tabular}




\begin{tabular}{|c|c|c|}
\hline & & $\begin{array}{l}\text { Users'+'Old Regime Unaware Users') //MAX(0,'Old Regime } \\
\text { Aware Users')/('Total New Regime Users'+'Old Regime } \\
\text { Aware Users'+'Old Regime Unaware Users') }\end{array}$ \\
\hline 183 & Regime resources sufficiency & $\begin{array}{l}\text { NUMBER('Regime Resource Usage')/'Production regime } \\
\text { resources' }\end{array}$ \\
\hline 184 & Total Resource Usage & 'Regime Resource Usage'+'Resource Usage' \\
\hline 185 & Total resources & $\begin{array}{l}\text { 'Production regime resources'+'Production resources of the } \\
\text { new regime' }\end{array}$ \\
\hline 186 & Total members & 'New regime members'+'Old regime members' \\
\hline 187 & Efficiency differential & New tech efficiency'/'Old tech efficiency' \\
\hline 188 & Total scientists & 'New Regime Scientists'+'Current Regime Scientists' \\
\hline 189 & Regime theory research & $\begin{array}{l}\text { (1-'Regime theory')*MAX(0,'Current Regime Scientists } \\
\text { Ratio') }{ }^{\star \prime} \text { Regime Total Resources Ratio'* }(1- \\
\text { NUMBER('Experimental Observation'*'Perceived } \\
\text { crisis'))/1<<yr>> }\end{array}$ \\
\hline 190 & $\begin{array}{l}\text { Resource Usage New } \\
\text { Regime }\end{array}$ & $\begin{array}{l}\text { MIN('New regime members'*'Outside total members } \\
\text { ratio','New Regime Capacity'*'New old capacity } \\
\text { ratio') }{ }^{\star} M A X(0, M I N(1, \text { 'Production resources of the new } \\
\text { regime') }) / 1<<y r>>\end{array}$ \\
\hline 191 & $\begin{array}{l}\text { Impact on natural } \\
\text { environment }\end{array}$ & $\begin{array}{l}\text { DELAYINF('Regime Environmental Impact','Delay in } \\
\text { environmental impact',1,'Regime Environmental Impact') }\end{array}$ \\
\hline 192 & Shift of resources & $\begin{array}{l}\text { MAX }\left(0 / 1<<y r>>,(' M e m b e r s h i p \text { shift') })^{\star} M I N(' P r o d u c t i o n\right. \\
\text { regime resources','New regime resource } \\
\text { shortage')*MAX(0,MIN(ROUND('Production regime } \\
\text { resources',0.1),1)) }\end{array}$ \\
\hline 193 & $\begin{array}{l}\text { Resources supply New } \\
\text { regime }\end{array}$ & $\begin{array}{l}\text { DELAYMTR('Resource Usage New Regime','Resource } \\
\text { supply adjust delay',1,'Resource Usage New } \\
\text { Regime')//*'Outside total members ratio'+MAX(0,MIN('New } \\
\text { regime resource shortage','New regime members'))/1<<yr>> }\end{array}$ \\
\hline 194 & Membership shift & 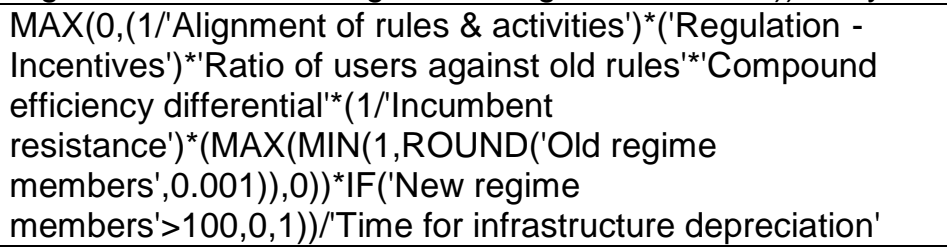 \\
\hline 195 & Regime Resource Usage & $\begin{array}{l}\text { MIN('Old regime members'*'Regime Total Members } \\
\text { Ratio','Old Regime Capacity'*'Old new capacity } \\
\text { ratio')*ROUND(MAX(MIN(1,'Production regime } \\
\text { resources'),0),0.001)/1<<yr>> }\end{array}$ \\
\hline 196 & Regime resource supply & $\begin{array}{l}\text { MAX(DELAYMTR('Regime Resource Usage','Resource } \\
\text { supply adjust delay',1,'Regime Resource } \\
\text { Usage')*ROUND('Regime Total Members Ratio',0.01)+'Old } \\
\text { regime resource shortage'/1<<yr }>>, 0 / 1<<y r>>)^{\star \prime} \text { Old New } \\
\text { users ratio' }\end{array}$ \\
\hline 197 & $\begin{array}{l}\text { Scientists Adopting New } \\
\text { Paradigm }\end{array}$ & $\begin{array}{l}\text { NUMBER('Regime Transition'*'Current Regime } \\
\text { Scientists'*MAX(0,MIN('Current Regime } \\
\text { Scientists',1))+'Experimental } \\
\text { Observation'*MIN(1,'Confidence in New } \\
\text { Regime')*MAX(0,MIN(ROUND('Current Regime } \\
\text { Scientists',0.001),1)))/'Time to retrain in new regime' }\end{array}$ \\
\hline 198 & $\begin{array}{l}\text { Current Regime Scientists } \\
\text { Retire }\end{array}$ & $\begin{array}{l}\text { MAX(0,ROUND('Current Regime Scientists',0.001))/'Years } \\
\text { as scientist' }\end{array}$ \\
\hline 199 & New Regime Scientists Die & 'New Regime Scientists'/'Years as scientist' \\
\hline 200 & Current Paradigm Education & $\begin{array}{l}\text { Candidate Scientists'*MAX(0,ROUND('Confidence in } \\
\text { Current Regime',0.001))/'Time to train in current paradigm' }\end{array}$ \\
\hline 201 & New Regime Education & $\begin{array}{l}\text { Candidate Scientists'*'Confidence in New Regime'/'Time to } \\
\text { train in new regime' }\end{array}$ \\
\hline 202 & Rate of Training & Scientists Training'/'Time for education' \\
\hline 203 & $\begin{array}{l}\text { Possibility of experimental } \\
\text { anomaly }\end{array}$ & $\begin{array}{l}\text { DELAYINF('Regime Environmental Impact','Observational } \\
\text { delay of regime effect',1,'Regime Environmental Impact') }\end{array}$ \\
\hline 204 & Rate of new theory research & $(1-'$ New theory')* 'Experimental Observation'*'Perceived \\
\hline
\end{tabular}




\begin{tabular}{|c|c|c|}
\hline & & $\begin{array}{l}\text { crisis' *'New Regime Scientists Ratio' *'Outside Total } \\
\text { Resources Ratio' }\end{array}$ \\
\hline 205 & Paradigm transition & $\begin{array}{l}\text { Number of experimental anomalies'^NUMBER('Rate of new } \\
\text { theory research')*MAX(ROUND('Confidence in Current } \\
\text { Regime',0.001),0)/('Years as scientist') }\end{array}$ \\
\hline 206 & Rate of crisis increase & $\begin{array}{l}\text { ('Number of experimental anomalies'-'Perceived } \\
\text { crisis')/1<<yr>> }\end{array}$ \\
\hline 207 & Experimental observations & $\begin{array}{l}\text { MAX(NORMAL('Impact on natural environment','Impact on } \\
\text { natural environment'/2,0.5),0) }\end{array}$ \\
\hline 208 & Experimental Observation & $\begin{array}{l}\text { IF ('Experimental observations'>'Possibility of experimental } \\
\text { anomaly',1,0)/1<<yr>> }\end{array}$ \\
\hline 209 & New tech efficiency change & 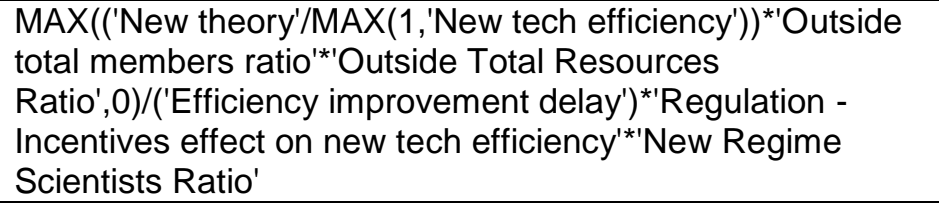 \\
\hline 210 & Old tech efficiency change & $\begin{array}{l}\text { ROUND(MAX(('Regime theory'/'Old tech } \\
\text { efficiency')*'Regime Total Members Ratio'*'Regime Total } \\
\text { Resources Ratio',0),0.001)/('Efficiency improvement delay') }\end{array}$ \\
\hline 211 & Alignment replenishment & $\begin{array}{l}\text { MAX((NUMBER('Max alignment'-'Rule System Alignment'))- } \\
\text { 'Decrease alignment' } 1<<y r>>, 0)\end{array}$ \\
\hline 212 & Check for zero alignment & MAX(MIN('Rule System Alignment',1),0) \\
\hline 213 & Decrease alignment & $\begin{array}{l}\text { MAX(0,(1-'Rule system stability'*'Alignment of activities')* } \\
\text { MIN('Political pressure'/MAX(1,RUNMAX('Political } \\
\text { pressure')),1) *'Check for zero alignment') } / 1<<y r>>\end{array}$ \\
\hline 214 & Increase Rule alignment & 'Alignment replenishment'/1<<yr>>*'Rule system stability' \\
\hline 215 & Coordination of activities & 1-STDEV('Rule System Alignment','Rule system stability') \\
\hline 216 & $\begin{array}{l}\text { Incumbent influence on } \\
\text { policy }\end{array}$ & $\begin{array}{l}\text { MAX('Incumbent resistance'-RUNMAX('Window of } \\
\text { Opportunity'),0) }\end{array}$ \\
\hline 217 & Pressure on the system & $\begin{array}{l}\text { ABS(NUMBER('Rate of change of perception of } \\
\text { needs'*'Perception of new needs'+'Political pressure } \\
\text { increase'*'Political pressure')*'Ratio of old regime users } \\
\text { against rules') }\end{array}$ \\
\hline 218 & Check for WoO & MAX(MIN('Max WoO'-'Window of Opportunity',1),0) \\
\hline 219 & WoO close & ('Window of Opportunity')/(ABS('New need')+1)/1<<yr >> \\
\hline 220 & WoO open & $\begin{array}{l}\text { DELAYINF('Pressure on the system','WoO open } \\
\text { delay', } 1, \text { 'Pressure on the system')/1<<yr }>\rangle^{* 1} \text { Check for WoO' }\end{array}$ \\
\hline 221 & Perception of regime effect & $\begin{array}{l}\text { DELAYINF('Regime Environmental Impact','Regime impact } \\
\text { perception delay time',1,'Regime Environmental Impact') } \\
{ }^{*} \text { 'New theory'*'INPUT Media influencing public' //'Old regime } \\
\text { users' }\end{array}$ \\
\hline 222 & Old regime effect rate & $\begin{array}{l}\text { (('Total old regime users')/('Old tech } \\
\text { efficiency'))/1<<yr>> }{ }^{* \prime} I N P U T \text { Old regime effect scenario' }\end{array}$ \\
\hline 223 & Check for target stability & 'Rule system stability'/'Max rule stability' \\
\hline 224 & Rule replenishment & $\begin{array}{l}\text { MAX((NUMBER('Max rule stability'-'Rule system stability'))- } \\
\text { 'Rule destabilization'*1<<yr }>>, 0) * \text { IF (('Perception of new } \\
\text { needs')<>0,1,0) }\end{array}$ \\
\hline 225 & Check for zero rule & MAX(MIN('Rule system stability',1),0) \\
\hline 226 & Rule destabilization & $\begin{array}{l}\text { (ABS('Perception of new needs')*'Ratio of users against old } \\
\text { rules'*MIN('Political pressure'/MAX(1,RUNMAX('Political } \\
\text { pressure')),1)*'Check for zero rule'*'Switch Rule System } \\
\text { Stability')/'Time for infrastructure depreciation' }\end{array}$ \\
\hline 227 & Rule in the making & $\begin{array}{l}\text { Rule replenishment'*'Check for target stability'/'Time for } \\
\text { infrastructure depreciation' }\end{array}$ \\
\hline 228 & New old users \% & $\begin{array}{l}\text { ROUND('Total New Regime Users'/('Total New Regime } \\
\text { Users'+MAX(0,'Old Regime Unaware Users'+'Old Regime } \\
\text { Aware Users')),0.001) }\end{array}$ \\
\hline 229 & New old capacity ratio & $\begin{array}{l}\text { 'New Regime Capacity'/MAX(1,('New Regime } \\
\text { Capacity'+'Old Regime Capacity')) }\end{array}$ \\
\hline 230 & Check investment coverage & MAX('Old Regime Production Capital'/'Regulation - \\
\hline
\end{tabular}




\begin{tabular}{|c|c|c|}
\hline & & Incentives',0) \\
\hline 231 & Old capacity decrease & 'Old Regime Capacity'/('Time for infrastructure depreciation') \\
\hline 232 & Old capacity increase & $\begin{array}{l}\text { MAX(('Old capacity decrease')*'Old capital capacity } \\
\text { ratio'+('Required old regime capacity'-'Old Regime } \\
\text { Capacity')/'Time to develop capacity',0/1<<yr>>) }\end{array}$ \\
\hline 233 & Investment shift & 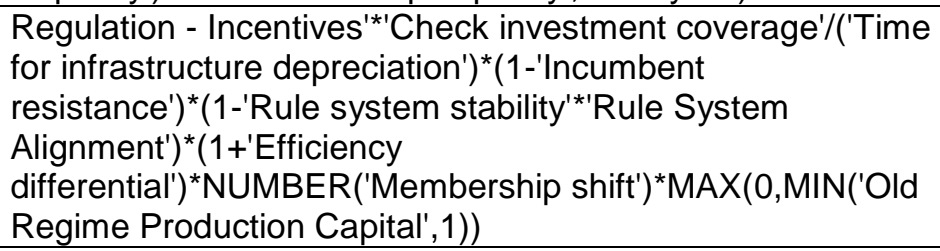 \\
\hline 234 & New user need & 'Old Regime Aware Users'/'Total users' \\
\hline 235 & Change in EoS old & $\begin{array}{l}\text { ('Old Regime Capacity'-'Economies of scale old')/'Time for } \\
\text { infrastructure depreciation' }\end{array}$ \\
\hline 236 & Change in EoS new & $\begin{array}{l}\text { ('New Regime Capacity'-'Economies of scale new')/'Time for } \\
\text { infrastructure depreciation' }\end{array}$ \\
\hline 237 & New Old users ratio & $\begin{array}{l}\text { ROUND('Total New Regime Users'/('Total New Regime } \\
\text { Users'+'Old Regime Aware Users'+'Old Regime Unaware } \\
\text { Users'),0.0001) }\end{array}$ \\
\hline 238 & $\begin{array}{l}\text { Decrease incumbent } \\
\text { resistance }\end{array}$ & $\begin{array}{l}\text { MAX }\left(0,(1-' A l i g n m e n t \text { of rules \& activities') })^{\star \prime} \text { Efficiency }\right. \\
\text { differential'*MAX(('Regulation - } \\
\text { Incentives')/MAX(1,('Incumbent resistance'*'Old Regime } \\
\text { Capacity' }))^{\star}(1-M I N(1, \text { 'Regime Total Members Ratio') }), 0)\end{array}$ \\
\hline 239 & Regulate flow & $\begin{array}{l}\text { IF ('Competitiveness diff'.'Regime shift direction'>0, ('Check } \\
\text { stock coverage'),0) }\end{array}$ \\
\hline 240 & Check users Level & $\begin{array}{l}\text { MIN(100,MAX((ROUND('Old Regime Aware } \\
\text { Users',0.01))/('Competitiveness diff'.'Competitiveness } \\
\text { diff'),0)) }\end{array}$ \\
\hline 241 & Total users & $\begin{array}{l}\text { 'Old Regime Aware Users'+'Total New Regime Users'+'Old } \\
\text { Regime Unaware Users' }\end{array}$ \\
\hline 242 & $\begin{array}{l}\text { Investment of resources for } \\
\text { process improvement } \\
\text { production capital }\end{array}$ & $\begin{array}{l}\text { 'New Old users ratio'*'Technical solution pilot } \\
\text { runs'*'Economies of scale new' }\end{array}$ \\
\hline 243 & $\begin{array}{l}\text { Threshold technical feasibility } \\
\text { of solution }\end{array}$ & 'Old regime competitiveness'/'Regulation - Incentives' \\
\hline 244 & New capacity decrease & 'New Regime Capacity'/'Time for infrastructure depreciation' \\
\hline 245 & New capacity increase & $\begin{array}{l}\text { (('Technical solution pilot runs'/MAX('New Regime } \\
\text { Capacity',1))/'Time to develop capacity'*('Investment of } \\
\text { resources for process improvement production } \\
\text { capital'/MAX('Technical solution pilot runs',1))+'Required } \\
\text { New Regime Capacity'/'Time to develop capacity'林w } \\
\text { Capital Sufficiency for Capacity investment')*(1-'New } \\
\text { Regime Capacity Shortage')+'New capacity decrease' }\end{array}$ \\
\hline 246 & Regulation - Incentives & $\begin{array}{l}\text { (DELAYINF('Political pressure'*(1-'Incumbent influence on } \\
\text { policy'),'Delay in regulation effects',1)*'Switch Regulation - } \\
\text { Incentives')*'Scope for Regulation Switch' +1 }\end{array}$ \\
\hline 247 & Political pressure decrease & $\begin{array}{l}\text { MIN('Political pressure',(1-'Perception of new } \\
\text { needs'))/'Political pressure change delay time'* }(1 \text {-'Incumbent } \\
\text { resistance'*'Perception of new needs')*'New Old users } \\
\text { ratio'*'Switch Political Pressure' }\end{array}$ \\
\hline 248 & Political pressure increase & $\begin{array}{l}\text { Perception of new needs'/'Political pressure change delay } \\
\text { time'*(1-'New Old users ratio')*'Switch Political Pressure' }\end{array}$ \\
\hline 249 & $\begin{array}{l}\text { Level of tech solution } \\
\text { diffusion }\end{array}$ & 'Total New Regime Users'/'Total users' \\
\hline 250 & Technical solution pilot runs & $\begin{array}{l}\text { MAX(ARRSUM('Niche R \& D')/MAX('Threshold technical } \\
\text { feasibility of solution',1),0) }\end{array}$ \\
\hline 251 & Flow of Financial Capital & $\begin{array}{l}\text { 'Perception of new needs'*'Regulation - } \\
\text { Incentives'*MIN( } 1 \text {,'New regime members') }\end{array}$ \\
\hline 252 & $\begin{array}{l}\text { Rate of change of perception } \\
\text { of needs }\end{array}$ & $\begin{array}{l}\text { ('New user need'-ROUND('Perception of new } \\
\text { needs',0.01))/('Need perception delay time')*('INPUT Media } \\
\text { influencing public') }\end{array}$ \\
\hline
\end{tabular}




\begin{tabular}{|c|c|c|}
\hline 253 & User Transition & $\begin{array}{l}\text { ('Competitiveness diff'.'Competitiveness diff'/'Delay in user } \\
\text { transition'*'Regulate flow'*'New old capacity ratio'**'New old } \\
\text { users \%'*(1-'Rule System Alignment'*'Rule system } \\
\text { stability')*('Regulation - Incentives')) }\end{array}$ \\
\hline 254 & New regime competitiveness & 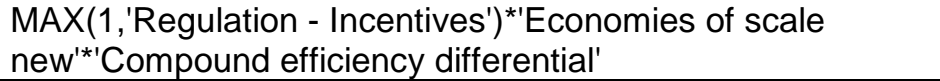 \\
\hline 255 & Old regime competitiveness & $\begin{array}{l}\text { Economies of scale old'/'Regulation - } \\
\text { Incentives'*IF('Compound efficiency } \\
\text { differential'=0,1,1/(0.02+ROUND('Compound efficiency } \\
\text { differential',0.01))) }\end{array}$ \\
\hline 256 & $\begin{array}{l}\text { Competitiveness } \\
\text { diff.Competitiveness diff }\end{array}$ & $\begin{array}{l}\text { MAX('New regime competitiveness','Old regime } \\
\text { competitiveness') *'Regime shift direction' }\end{array}$ \\
\hline 257 & $\begin{array}{l}\text { Competitiveness diff.New old } \\
\text { ratio }\end{array}$ & $\begin{array}{l}\text { 'New regime competitiveness'/MAX(1,'Old regime } \\
\text { competitiveness') }\end{array}$ \\
\hline 258 & $\begin{array}{l}\text { Competitiveness diff.New } \\
\text { regime competitiveness }\end{array}$ & Parent $\sim$ 'New regime competitiveness' \\
\hline 259 & $\begin{array}{l}\text { Competitiveness diff.Old new } \\
\text { ratio }\end{array}$ & $\begin{array}{l}\text { 'Old regime competitiveness'/MAX(1,'New regime } \\
\text { competitiveness') }\end{array}$ \\
\hline 260 & $\begin{array}{l}\text { Competitiveness diff.Old } \\
\text { regime competitiveness }\end{array}$ & Parent 'Old regime competitiveness' \\
\hline 261 & $\begin{array}{l}\text { Competitiveness diff.Regime } \\
\text { shift direction }\end{array}$ & $\begin{array}{l}\text { IF ('New old ratio'>'Old new ratio',1,-1)*IF('New old } \\
\text { ratio'='Old new ratio',0,1) }\end{array}$ \\
\hline 262 & $\begin{array}{l}\text { User } \\
\text { Choice.Competitiveness diff }\end{array}$ & 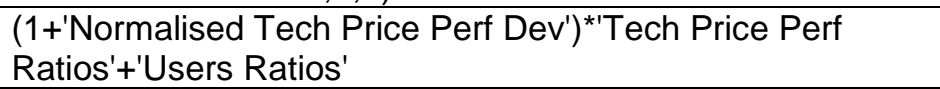 \\
\hline 263 & $\begin{array}{l}\text { User Choice.Min Tech Price } \\
\text { Perf Dev }\end{array}$ & ARRMIN('Tech Price Perf Dev') \\
\hline 264 & $\begin{array}{l}\text { User Choice.Normalised } \\
\text { Tech Price Perf Dev }\end{array}$ & 'Tech Price Perf Dev'+ABS('Min Tech Price Perf Dev') \\
\hline 265 & $\begin{array}{l}\text { User Choice.Price Perf } \\
\text { ArrSum }\end{array}$ & ARRSUM('Price Perf Ratio') \\
\hline 266 & User Choice.Price Perf Avg & ARRAVERAGE('Price Perf Ratio') \\
\hline 267 & User Choice.Price Perf Ratio & Parent $\sim$ 'Perf Price Ratio' \\
\hline 268 & $\begin{array}{l}\text { User Choice.Tech Price Perf } \\
\text { Dev }\end{array}$ & $\begin{array}{l}\text { FOR (i=TechRange|'Price Perf Ratio'[INDEX(I)]-'Price Perf } \\
\text { Avg') }\end{array}$ \\
\hline 269 & $\begin{array}{l}\text { User Choice.Tech Price Perf } \\
\text { Ratios }\end{array}$ & $\begin{array}{l}\text { FOR (i=TechRange|'Price Perf } \\
\text { Ratio'[INDEX(i)]/MAX(1,'Price Perf ArrSum')) }\end{array}$ \\
\hline 270 & User Choice.Total Users & ARRSUM(Users) \\
\hline 271 & User Choice.Users & Parent 'Niche Users' \\
\hline 272 & User Choice.Users Ratios & FOR (i=TechRange|Users[INDEX(i)]/MAX(1,'Total Users')) \\
\hline 273 & Niche Required Capacity & $\begin{array}{l}\text { 'Total Niche Users per Tech'*'User Capacity Conversion } \\
\text { Factor' }\end{array}$ \\
\hline 274 & Total Niche Users per Tech & 'Niche Users'+'Allocate Potential New Niche Users' \\
\hline 275 & $\begin{array}{l}\text { Allocate Potential New Niche } \\
\text { Users }\end{array}$ & $\begin{array}{l}\text { PRIORITYALLOC('Potential New niche Users',\{'Potential } \\
\text { New niche Users','Potential New niche Users','Potential New } \\
\text { niche Users'\},'Niche Users') }\end{array}$ \\
\hline
\end{tabular}

